\title{
Palabras para paulo Freire. Saludos locales e internacionales
}

\section{Palavras para Paulo Freire. Saudações locais e internacionais Words for Paulo Freire. Local and international greetings}

Paulo Freire. Uma Obra Cinquentenária no seu Centenário José Eustáquio Romão

Carta a Paulo Freire

Emília Maria Da Trindade Prestes

A luta continua

Lauren Ila Misiaszek

De Angicos [Brasil, 1963] a Valência [Espanha, 1995] para o mundo - Paulo Freire: um legado de esperança

Maria da Salete Barboza de Farias

Adriana Valéria Santos Diniz

Carta de indignação e esperança [ao mestre Paulo Freire]

Uyguaciara Veloso Castelo Branco

É tempo de travessia: diálogos com Paulo Freire

Edna Gusmão de Góes Brennand

Paulo Freire: genialidade na simplicidade

Elda Silva do Nascimento Melo

Freirean reinvention and hope to construct teaching to save Earth: Ecopedagogy

\section{Greg William Misiaszek}

Para Paulo Freire e Valência

Talamira Taita Rodrigues Brito

Sentipensar Freire

María-Jesús Martínez-Usarralde 
El legado de Paulo Freire en la Universidad

Miguel Ángel Guillamón Blasco

Pese a todo, tenemos pequeños oasis de esperanza Jordi Llacer Folch

Tribute to Paulo Freire Maria del Pilar O`Cadiz

Celebrando Paulo Freire

Manuela Guilherme

O sonho possível!

Edineide Jezine

Por un mundo mejor

Alejandra Montané López

Minha homenagem ao Prof. Paulo Freire

Betania Ramalho

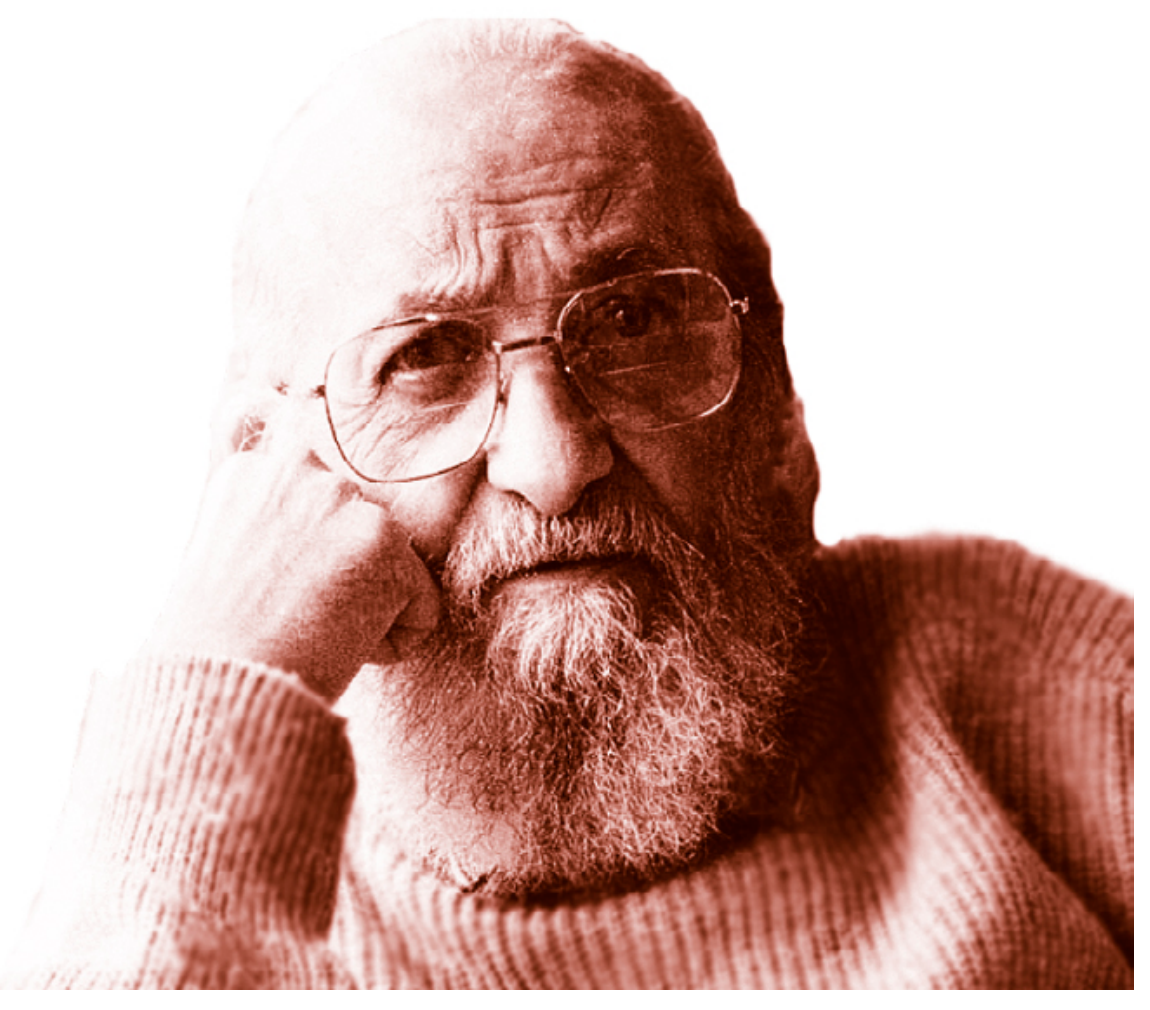




\section{Paulo Freire \\ Uma Obra Cinquentenária no seu Centenário José Eustáquio Romão}

Rememorando a notável conferência de Paulo Freire, em 1995, na Universidade Internacional Menéndez Pelayo [UIMP], em Valência, a convite do Ministério Regional da Educação e do Gabinete de Agentes Sociais para a Formação Permanente de Adultos, o Professor José Beltrán, da mesma Universidade, convidou-me a escrever uma saudação ao ilustre conferencista. Confesso que, ainda que muito honrado com o convite, embaracei-me, depois, com o que seria a natureza e a estrutura da escrita de uma "saudação", nas efemérides dos 25 anos de uma conferência pronunciada pelo Patrono da Educação Brasileira e um dos mais conhecidos educadores e pensadores do século XX em terras do País Valenciano.

Lembrei-me, então, de uma fala de Freire, com o qual tive o privilégio de conviver por cerca de quase duas décadas - de seu retorno do exílio de quase vinte anos ao Brasil, em 1980, até seu falecimento em 2 de maio de 1997 - de que a melhor maneira de homenagear alguém, especialmente se não estiver mais no mundo dos vivos, é demonstrando a atualidade de sua obra.

Assim, depois de 50 anos da primeira edição de Pedagogia do oprimido, supostamente em espanhol, numa publicação da Editora Tierra Nueva, no Uruguai ${ }^{2}$, e depois de quase um século do nascimento de Paulo Freire, em 19 de setembro de 1921, penso que seriam oportunas algumas palavras desta saudação serem dedicadas à obra mais conhecida de Paulo Freire, ou melhor a alguns aspectos da criação e da edição desse livro, hoje, um dos mais editados, traduzidos e demandados pelo mundo, portanto, um clássico da produção da mente humana. E um "clássico" se caracteriza por sua eternidade, ainda que provocando diferentes leituras para permitir suas "reinvenções contextuais", como que atendendo ao próprio apelo reiterado de Freire: "Não me repitam; reinventem, se for o caso, minhas ideias que tenham algum valor, em cada novo contexto".

Quem se aproxima de Pedagogia do oprimido já percebe, de início, que não se trata apenas de um texto orientador da alfabetização e educação de adultos, mas, muito mais do que isso, tratase de um verdadeiro tratado de "ontologia" e de "epistemologia"3.

1 Secretário Geral do Conselho Mundial dos Institutos Paulo Freire; Diretor Fundador do Instituto Paulo Freire do Brasil e Professor e Diretor do Programa de Pós-Graduação da Universidade Nove de Julho [UNINOVE], Brasil. E-mail: jerromao@gmail. com.

2 A versão mais conhecida é de que a primeira edição teria sido em inglês, nos Estados Unidos, mas, tudo leva a crer que a publicação no Uruguai teria precedido em cerca de três meses a estadunidense, conforme pesquisa recentemente realizada por Federico Brugaletta.

3 Ambos os termos devem ser colocados entre aspas, seja porque Paulo Freire considerava que o "ser" não é, "está sendo", o que torna o termo "ontologia" [teoria do ser] inadequado, ao mesmo tempo que "epistemologia" [a teoria do conhecimento científico] é tampouco adequada, na medida em que uma teoria que explique todos os modos de conhecer humano também não existe; seja porque ambas deveriam ser grafadas no plural, já que qualquer concepção humana é uma entre várias. Talvez, na perspectiva freiriana, fosse mais conveniente falar em uma Sociologia-Histórica do Conhecimento. 
"Ontologicamente", Paulo Freire inovou ao considerar o ser humano como incompleto [precisa de outrem], inconcluso [está em transformação] e inacabado [é imperfeito] e que, diferentemente dos outros "seres", que também são incompletos, inconclusos e inacabados, tem consciência dessas limitações e, por isso, apresenta-se permanentemente insatisfeito com sua "natureza" de "ser", querendo, obsessivamente, "ser mais". Contudo, não consegue nem uma coisa nem outra: não é o "ser" que não deseja mais ser e nem é o "ser mais" que ainda vai ser. Em conclusão, o ser humano é o "sendo". Em suma, os humanos somos essa tensão permanente entre "ser" e "ser mais".

"Epistemologicamente", este "sendo" só subsiste com a também permanente busca do conhecimento para "ser mais". Mas, esse conhecimento só se constrói coletivamente, pelos homens e mulheres "em comunhão, mediatizado[s] pelo mundo" [FREIRE, 2018, p. 165] ${ }^{4}$. Para Freire, o sujeito da criação cultural é mais do que coletivo, é transcultural, na medida em que o conhecimento novo somente pode ser resultante da ação de um ator ${ }^{5}$ novo, constituído pelo somatório dos atores individuais, mas a cujo conjunto se acrescenta uma determinada qualidade cognoscitiva. Para dar um exemplo paralelo, imaginemos que uma peça muito pesada precisa ser carregada de um lugar para outro, em uma mudança. A soma das forças de várias pessoas para levantar a peça pode ser insuficiente se for aplicada a um mesmo ponto da peça a ser levantada; se, no entanto, além dessa soma, cada um aplicar a própria força individual em diferentes pontos da peça, certamente ela poderá ser levantada e carregada. 0 mesmo ocorre com 0 conhecimento inédito: construído a partir dos conhecimentos individuais discutidos criticamente e referenciados no mundo, isto é, na solução dos problemas que a humanidade se põe, seja em termos racionais [ciência], seja em termos estéticos [arte], seja em termos espirituais (religião].

Pedagogia do oprimido teve sua redação terminada na primavera de 1968, conforme Paulo Freire registrou na dedicatória que fez do manuscrito a Jacques Chonchol (ministro de Salvador Allende], em Santiago do Chile.

Como o próprio Paulo Freire explica em Pedagogia da esperança: um reencontro com a Pedagogia do oprimido [1992], esta última obra foi elaborada por meio de um processo transindividual de criação: cada parte escrita era submetida a dezenas de leitores e Freire ainda expunha partes do que havia redigido a públicos variados em eventos, a ponto de ser alertado pela filha Maria Madalena que ele estava divulgando um livro que ainda não existia:

Levei um ou mais de um ano falando de aspetos de Pedagogia do oprimido. Falei a amigos que me visitavam, discuti-o em seminários, em cursos. Um dia, minha filha Madalena chegou a chamar, delicadamente, minha atenção para o fato. Sugeriu maior contenção de minha parte na ânsia de falar sobre a Pedagogia do oprimido ainda não escrita. Não tive forças para viver a sugestão. Continuei apaixonadamente falando do livro como se estivesse, e na verdade estava, aprendendo a escrevê-lo [FREIRE, 1992, p. 54].

$4 \quad 0$ parágrafo completo, que sintetiza uma das categorias mais importante do pensamento freiriano é: "Já agora ninguém educa ninguém, como tampouco ninguém se educa a si mesmo; os homens se educam em comunhão, mediatizados pelo mundo. Mediatizados pelos objetos cognoscíveis que, na prática 'bancária' são possuídos pelo educador que os descreve ou os deposita nos educandos passivos" [FREIRE, 2018, p. 165).

5 Preferimos a palavra "ator", de atuar, agir, do que o vocábulo "sujeito", que remete também a "submetido", "dominado", "oprimido". 
Além disso, Freire recolhia as sugestões e submetia à leitura final de Elza, a esposa, que era sua grande referência em educação. No caso específico de Pedagogia do oprimido, ocorreu ainda mais uma socialização da escrita, mesmo já tendo entregue os originais, com três capítulo apenas, ao prefaciador, Ernani Maria Fiori, e ter recebido a obra de volta com o prefácio escrito: Freire narra que, recebendo a visita de Josué de Castro em Santiago e discutindo com ele os originais do livro, recebeu a sugestão de guardá-los por uns meses, para depois retornar a eles, lêlos e, só então, publicá-lo. Obedecendo à sugestão, Freire guardou os originais, resultantes de um "trabalho artesanal" lenta e socialmente comungado, sintetizado a partir de "fichas geradoras", de acordo com a própria explicação de Freire [id., ibid., p. 58 e 59]. Quase não contendo uma ansiosa vontade de reler o texto "em quarentena" antes do prazo sugerido (quatro meses): "Na noite do mesmo dia em que Fiori me entregou seu texto, após lê-lo e aos três capítulos da Pedagogia, os tranquei a todos por dois meses..." [id., ibid., p. 60).

Freire resolveu acrescentar mais um capítulo, o quarto, depois de reler os originais após a "quarentena" sugerida por Josué de Castro, encaminhando-a a editores de vários países, menos ao do próprio país natal, onde estava condenado em um Inquérito Policial Militar (IPM] e, por isso, proibido de ser lido no território nacional. O livro foi publicado, ao que se sabe até agora, em seis países antes de ser editada no Brasil: pela ordem, Uruguai (Tierra Nueva, 1970), Estados Unidos [The Seabury Press, 1970], Itália [Mondadori, 1971], Alemanha [Kreuz-Velag, 1971], Portugal (Afrontamento, 1972], França (Maspero, 1974). Sua edição no Brasil passou antes por uma verdadeira epopeia: para penetrar no país, os originais foram "contrabandeados" pelo Professor e Conselheiro Nacional suíço Jean Ziegler, que passou incólume pela alfândega ludibriando a censura oficial. "Sua publicação aqui, sua primeira impressão só foi possível em 1975" [FREIRE, 1992, p. 63], portanto, somente depois da edição francesa, em 1974. Embora, o editor, Fernando Gasparian, tenha recebido os originais em 1970, sugeriu aguardar "tempos mais favoráveis para sua publicação" [id., ibid.] e ainda assim, suprimiu, com a concordância de Freire, o desenho que ele fizera na página 15 de IV Capítulo do manuscrito confrontando a Teoria da Ação Revolucionária contra a Teoria da Ação Opressora, o que chamaria muito a atenção do censor oficial ${ }^{6}$. Esse tipo de censura ou de autocensura, sem falar nas mutilações, pelos mais diversos motivos [alguns confessáveis; outros nem tanto] continuam sendo aplicadas nas novas edições da obra. Daí a importância da publicação de Pedagogia do oprimido a partir de facsimile dos manuscritos [perfeitamente legiveis em português], porque tudo leva a crer que estes originais resultaram de um trabalho cuidadoso de Freire, que copiou à mão todo o livro, a partir dos originais que estavam datilografados, segundo as próprias palavras de Freire em Pedagogia da Esperança [1992].

Em conclusão, a verdadeira epopeia à procura dos originais, por mais de quinze anos, e a luta pelo convencimento dos editores que vêm publicando a obra valeu a pena. É claro que nada disso seria possivel se não fosse a generosidade da família - filhos do primeiro casamento de Freire com Elza e herdeiros dos direitos autorais para a publicação da obra impressa -, mesmo que em edição limitada, não comercializável e para distribuição gratuita a bibliotecas e editoras, bem como por sua liberação total para a edição na versão digital, compreendendo que o mundo do

6 Lembrar que durante os governos militares no Brasil fora estabelecida a censura prévia a qualquer produção cultural [livros, filmes, peças teatrais etc.] que, para ser divulgada, tinha de apresentar o certificado correspondente de autorização do censor. Se alguém fosse pego, por exemplo, com um livro que não tivesse o certificado de censura prévia era punido, podendo, inclusive, ser preso. 
século XXI merece conhecer a obra máxima de Paulo Freire na sua autenticidade "decente" , ou seja, sem qualquer censura, autocensura, enfim sem qualquer mutilação ou alteração intencional ou astuciosa.

\section{Referências Bibliográficas}

Freire, Paulo. Pedagogia da esperança: um reencontro com a Pedagogia do oprimido. São Paulo: Paz e Terra, 1992.

Freire, Paulo. Pedagogia do oprimido: [o manuscrito]. São Paulo: Ed. UNINOVE, Ed, L do Instituto Paulo Freire; BT Acadêmica, 2018.

7 Depois de revisar a 15a . edição brasileira da edição de Pedagogia do oprimido e conferido suas correções em edição posterior [na17ª . edição], Freire escreveu, numa dedicatória de um exemplar oferecido ao casal Moacir e Rejane Gadotti: “Esta é a primeira edição decente de Pedagogia do oprimido". 


\section{Carta à Paulo Freire}

\section{Emília Maria Da Trindade Prestes ${ }^{8}$}

Querido Paulo, em meio a todas essas festividades para a comemoração do seu centenário, decidi lhe escrever essa carta, esperando que os emissários encontrem o seu destino.

Talvez você se espante em recebê-la, depois de tantos anos de ausências. Ocorre que, a exemplo daquela sua Carta a Guiné Bissau e também da que você escreveu aos professores, em 1993, decidi lhe saudar através dessa missiva, que tem um teor quase autobiográfico. Acredito que você, como um bom contador de história, deva estar acostumado com essa forma de escrita. Lembro que você costumava contar as histórias da sua vida, das suas viagens, das suas descobertas e das suas esperanças. Aliás, no seu livro "A sobra da mangueira", você relembra a sua infância quando, debaixo de arvores fez as primeiras leituras de mundo e da palavra. Olhando para as suas origens você pensou o mundo e a sua transformação. Esse não é o meu caso, evidentemente. Estou aqui para lhe saudar e lhe contar, como você se fez presente na minha vida. Câmara Cascudo, famoso antropólogo norte rio-grandense, em seu livro autobiográfico, escreveu: Vou peregrinar ao derredor de mim mesma, na companhia do tempo. Neste caso, vou peregrinar na companhia das suas ideias e nos relatos e posicionamentos de alguns dos seus amigos, em diferentes tempos.

Nos anos de 1960, quando você vivenciava a sua experiência de alfabetização em Angicos, eu era uma adolescente que iniciava meus estudos ginasiais em um colégio público de Natal. Talvez, dada a pouca idade, eu desconhecia as suas realizações e projetos educativos voltados para a alfabetização transformadora. Um pouco mais tarde, integrei-me aos quadros da Juventude Estudantil Católica [JEC], famosa por sua atuação no cenário social. Entretanto, ali seu nome não era conhecido, possivelmente devido as amarras do contexto pós 1964, sob o regime militar. Mesmo nos anos de 1970, já cursando a Universidade, na área social, você continuava omitido dos nossos currículos e estudos. 0 que eu, entretanto, considero mais estranho foi você continuar ignorado no curso de mestrado em Educação de Adultos, da Universidade Federal da Paraíba, onde realizei a minha formação de pós-graduação. Naqueles anos de 1980, a região nordestina ostentava cerca de $55,0 \%$ de pessoas de mais de 14 anos analfabetas, o que tornava o curso de mestrado em educação de adultos - o único do país, uma prioridade educativa para atender ao modelo de desenvolvimento nacional. A nação, com a extinção dos programas de educação de adultos anteriormente existentes, demandava pessoas qualificadas para atuar na escolarização do adulto, tornando-o capaz de acompanhar o surto de modernização, como era previsto nos documentos e discursos oficiais. Mesmo assim, já quase ao final do curso, você se fez presente na minha vida através de uma professora do mestrado considerada "revolucionária e meio louca", de nome Elisa. Foi ela quem nos apresentou a você, através dos seus livros: Pedagogia do Oprimido e Educação como Prática de Liberdade.

Lembro que nessa época você retornou do exílio e sua presença enchia estádios e ginásios para se ouvir a voz do educador que pregava em todo o mundo a Pedagogia da Libertação. 0

$8 \quad$ Universidade Federal de Paraíba 
Brasil recuperava o seu regime democrático e, a partir de então, seus livros e seus enfoques educacionais e políticos passaram a ser amplamente divulgados e adotados nos processos educativos formais e não formais, sugerindo um novo olhar e uma ação para a transformação do cenário nacional. Quando conclui o meu mestrado, isso metade dos anos de 1980, decidi fazer doutorado. Nesta época Ihe fiz uma visita informal, durante umas férias que você e sua família passaram em uma praia de João Pessoa, lembra? Por sua sugestão, fui fazer meu doutorado na cidade do México e você nunca soube como isso mudou toda a minha vida. Obrigada Freire!

Na cidade do México, final dos anos de 1980, conheci João Francisco de Sousa, seu discípulo e amigo. Ele, que na ocasião ostentava um enorme bigode - creio, para homenagear Zapata, escrevia uma tese sobre a Democracia dos Movimentos Sociais Populares. A sua preocupação era a de "potencializar e concretizar a criação de sucesso escolar para os setores populares a partir do debate sobre o multiculturalismo e as possibilidades da interculturalidade". Comentava que as novas propostas pedagógicas para a Educação de Adultos deveriam ser sintetizadas num enfoque de Educação Popular, situando-a do ponto de vista histórico e teórico no amplo espectro do debate latino-americano e internacional. Dizia que essa deveria ser a nova leitura dos seus enfoques educativos, Freire.

Quando voltei ao Brasil, na década de 1990, o mundo se encontrava em um contexto de mudanças. As crises e rupturas de antigos paradigmas teóricos e políticos, aliadas ao novo modelo econômico, ampliava a visibilidade do individualismo e do consumo, marcando as pautas da economia, das políticas e da educação. Neste novo contexto, comentava-se em determinados círculos da universidade brasileira que a educação popular estava ultrapassada pela nova modernidade. Também se comentava, Freire, que as suas ideias eram inadequadas e incompatíveis com as "novas exigências" de um mundo que se "pós-modernizava" na suas complexidades e seus problemas. Um mundo que presenciava " $\mathrm{O}$ fim da história”. Este era um contexto em que se dizia que a educação, sobretudo a educação de adultos, deveria estar voltada para o mercado e para o controle da qualidade. Apesar desses posicionamentos que circulavam nos meios brasileiros e da América Latina, existiam os grupos e pessoas resistentes que teimavam preservar as suas ideias, considerando a educação um meio para se atingir a humanidade, o respeito ao outro e a liberdade. João Francisco, seu parceiro de tantas histórias, continuava defendendo a vigência da sua obra, como uma forma de compreender o confuso e difuso final do século XX. A base da sua fundamentação se apoiava em uma concepção de educação como atividade cultural e de desenvolvimento da cultura, assim como de respeito ao Outro, tido como diferente.

Foi durante esses anos de embates educacionais e dualismos ideológicos que você, como Secretário de Educação da cidade de São Paulo, defendeu a escola pública como espaço de organização política das classes trabalhadoras e como um direito a ser assegurado a todas as pessoas como meio de auto emancipação. Na metade dos anos de 1990 o seu coração, exposto a tantos embates, mas, também, a tantas esperanças, não suportou o peso da realidade cruel vivenciada por países e grupos oprimidos e você nos deixou, legando-nos, todavia, seus livros, suas ideias e seus ideais.

A passagem do tempo me fez viajar a Barcelona para realizar um pós-doutorado, isso em 2003. Frequentando o Centro de Educação Social e Educativa - CREA/UB, dirigido pelos professores Ramón Flecha e Rosa Valls, com enfoques para a educação de adultos, para a exclusão e para a diversidade cultural, constatei, com alegria, que você continuava mais vivo do que nunca. Suas 
ideias subsidiavam os inúmeros trabalhos acadêmicos de pesquisa e de extensão ali realizados e, ao lado de outros teóricos como Habermas, Giddens e Touraine, você era reconhecido como um dos autores "mais influente dentro da literatura educativa e, também, o pedagogo com 0 maior número de referências nas ciências sociais em geral". Suas obras eram citadas por dois dos mais importantes bancos de dados das ciências sociais daquele momento: o Social Fire e o ERIC. Saindo do Brasil pude confirmar que a sua teoria dialógica, seu enfoque comunicativo e o seu pensamento, ancorado no diálogo, no respeito ao outro diferente e na busca de justiça social, continuavam oferecendo subsídios para explicar e justificar o momento de transição do inicio do século XXI.

Ali em Barcelona, me deparei, outra vez, com João Francisco - agora sem bigode e ares de Pablo Picasso, se propondo a realizar uma pesquisa sobre educação de adulto no CREA. A sombra da Igreja Sagrada Família, João Francisco me comentou as suas experiências como secretário de educação da cidade de São Paulo; que essa nova função de gestor lhe havia ampliado reflexões sobre os problemas emergentes dessa sociedade multicultural e diversificada; e, como todos estes problemas estavam se repercutido na escola. Que a nova experiência com o fazer educativo institucionalizado the permitiu formular novas concepções de pedagogia, de formação docente e de gestão, questões sempre problemáticas e acentuadas pelos novos tempos, em suas complexidades.

Observei que, em um mundo velozmente em modificação, você continuava acreditando e defendendo a educação como uma das poucas saídas para a inserção do indivíduo numa sociedade ameaçada por modificações provocadas pelo individualismo e o consumo. 0 novo mundo em formação, cujas formas de opressões iam adquirindo novas configurações, parecia revogar os ideais que sustentaram as grandes utopias anteriores. Nas novas conjunturas, agora globalizadas, concepções de liberdade e de cidadania pareciam anacrônicas, diante das novas formas de valorização do sujeito baseadas na eficiência e habilidades para o mundo do trabalho. Em contrapartida, no âmbito da nova utopia social, surgem novas reivindicações das culturas, demandando o respeito e a aceitação das diferentes maneiras de convivência humana nos campos da economia, da política, da religião, da etnia, do gênero, dos saberes e da interpessoalidade. Nesta nova atmosfera, a dimensão moderna da educação política parecia afastar-se das lutas assentadas nas classes sociais para centrar-se no singular, no particular, no sujeito e nas suas referencias identitárias.

Enquanto isso, na inquietante realidade sócio cultural excludente da região nordeste brasileira, berço das motivações iniciais que moveram os seus ideais educacionais no passado, as desigualdades continuavam se fazendo presentes, apesar da modernidade globalizada e dos avanços em termos de escolarização, movimentos sociais e ações das políticas públicas. Ali, as enormes diferenças sociais e econômicas e educacionais continuam marcadas, revelando a manutenção de cerca de dois terços de sua população jovem e adulta sem saber ler e nem escrever ou detentoras de precária escolarização. Mas isso não significa, Freire, que as suas lições em vida e o seu acervo pedagógico não tenham logrado êxito. Nota-se que cresce o número de pessoas e de movimentos que continuam acreditando nas possibilidades de superação de situações desumanizante, através do diálogo e da amorosidade.

Creio, inclusive, que essas concepções, gradativamente aplicadas em diferentes espaços socioculturais e educacionais; no campo, na cidade, nas periferias e centros urbanos e nas instituições educativas, contribuíram para que você se tornasse cada vez mais visível e contemplado 
com o título de Patrono da educação brasileira, isso em 2012. Depois do patronato foi a vez de se tornar o mentor do Marco de Referencia da Educação Popular para as Políticas Públicas democráticas, lançado pelo governo brasileiro em 2014. Recordo como essa institucionalização da educação popular provocou embates e posições contrárias entre os seus seguidores. De um lado havia quem considerasse esse Marco de Referência uma "traição" ao seu pensamento e memória, uma vez que nem o Estado e nem as suas políticas eram confiáveis. Por outro lado, existia quem defendesse a iniciativa, relembrando a sua visão grasmciana do Estado ser um espaço sociocultural em constante disputa. Por isso alegava que o espaço público é capaz de promover educação e cultura com políticas institucionais justas. Foi durante esses anos que João Francisco foi ao seu encontro.

Quero Ihe confessar que, igual a você, gosto de ver o mundo, de conhecer pessoas, de vivenciar novas experiências e aprendizagens. Por isso, em 2015, voltei a me auto exilar, dessa feita em Valência, para realizar um pós doutorado sênior. Na Universidade de Valencia fui trabalhar com o professor José Beltrán, um freireano convicto, que você conheceu bem durantes as suas passagens por aquela Universidade. Durante um ano, sob a sua supervisão, vivenciei muitos exemplos de como era possível associar a palavra escrita e oral às ações transformadoras. As lições aprendidas sobre as suas pedagogias, reforçaram as minhas convicções sobre a natureza política da educação e sobre a reconstrução da cidadania, através da reinterpretação dos postulados da pedagogia do oprimido. Professor Beltran costumava comentar que, na atualidade, a luta pela denuncia da opressão deve vir acompanhada da luta pelo reconhecimento e pela autonomia dos sujeitos.

Você há de convir que, contemporaneamente, o novo espaço social deve ser organizado de forma que as pessoas diferentes se respeitem e respeitem a cultura do outro. Aliás, anos de 1990, em um dos seus últimos livros, Pedagogia da Esperança, você já sinalizava essas novas preocupações sociais, ao reconhecer a história como luta e possibilidade de transformação e dizendo haver necessidade de se discutir temas vinculados a democracia, autonomia e a identidade cultural. É verdade que o modelo de sociedade, baseado na comunicação e na informação, vem ampliando as desigualdades e a aceitação passiva de processos decisórios pelos quais você tanto debateu. De todo modo, uma das lições dos processos históricos é que nenhum sistema ou instituição possui regras políticas e morais suficientemente resistentes e imutáveis; toda cultura ou forma de convivência é dinâmica. Creio, inclusive, que o desenvolvimento da história deve ser o de luta e de possibilidade de transformação, como você acentuava em Pedagogia do Oprimido e em Pedagogia da Esperança.

Se por um lado, continuamos a repetir ensinamentos ou a utilizar estratégias pedagógicas que praticamente não tem mais lugar em nossa modernidade tardia; se no contexto contemporâneo necessitamos de maior e melhor esclarecimentos conceituais sobre os termos "emancipação", liberdade" "opressões, direitos humanos ou justiça social evitando redundâncias, - como apontam alguns dos seus críticos -, entendo que, na realidade social fugidia das escolas públicas contemporâneas, dos movimentos sociais, da educação do campo e dos processos de educação de adultos, a vida se recria e as aprendizagens que não se revelam aos olhos menos atentos são capazes de se manifestarem em formas pedagógicas e em formas de convivências inovadoras e surpreendentes. Essas escolas "vivas" e muitas vezes invisiveis ao nosso olhar desatento e não crítico são aquelas capazes de assumirem compromissos com as rupturas de uma situação desigual, injusta e discriminadora, fortalecendo os laços de solidariedade e as alternativas contra 
o fatalismo da reprodução, da reprovação ou da exclusão dos setores populares. Alternativas de combate contra os preconceitos existentes em diversos setores da sociedade global.

A luta contra a pobreza, as desigualdades e discriminação por meio da educação deve continuar sendo parte da construção dos relatos históricos e das aprendizagens. Talvez estas aprendizagens sejam capazes de incluir os direitos e aspirações dos diferentes grupos [crianças, jovens, adultos e idosos; imigrantes, ciganos, indígenas, nômades, refugiados, deficientes, privados da liberdade, entre outros]; aprendizagens orientadas para a promoção da cooperação, da humanização e da solidariedade nacional e internacional, presentes nas suas ideias e nos seus ideais.

Vou finalizar essa carta Paulo; alonguei-me demais. Antes, porém, gostaria de reafirmar as minhas convicções sobre as possibilidades dos indivíduos se [re] descobrirem como pessoas e se tornarem capazes de mudar as suas próprias historias e daí transformarem o mundo. Talvez seja justamente por essa possibilidade de "pensar a educação" como possibilidades de mudanças que as suas ideias pedagógicas continuem renovadas e atemporais.

Concluo lembrando a musica, 'A canção das Américas', que fala sobre o encontro futuro dos amigos. $O$ futuro já se fez presente no encontro entre você e João Francisco. E é bem provável que, em algum ponto do infinito, vocês estejam juntos e dialogando sobre a educação, suas utopias e suas práticas de liberdade. Um afetuoso abraço, 


\section{A luta continua}

\section{Lauren Ila Misiaszek}

La provincia de Valencia siempre ha sido un referente intelectual importante para mí, tanto durante mi tiempo como estudiante de intercambio de la Universidad de Valencia como durante mi visita como investigadora al Instituto Paulo Freire, España, y continuamente a través de toda la importante praxis que la región da al mundo, lo cual sigue inspirando mi compromiso con nuestro trabajo freireano.

Valencia también ha sido un referente personal muy influyente y, en el espíritu de educación informal y trabajo cultural, especialmente de las mujeres, quisiera también honrar a mi "mamá Valenciana," la Sra. Marite Oller Escuder, que cumple 80 años este 15 de octubre. En su casa, a lo largo de muchas décadas, con mucha sabiduría y paciencia y con una mente siempre muy abierta, informalmente educaba a más de 70 mujeres jóvenes estudiantes de intercambio como yo - pienso que Freire hubiera apreciado mucho este trabajo muy importante pero muchas veces invisible. Para muchas de nosotras, Marite, una mujer fuerte e independiente que ha superado muchos desafíos en la vida, también mamá y abuela biológica y líder comunitaria, es la persona que más nos ha ayudado a entender las diversas realidades socioculturales españolas, un buen ejemplo de la humanización freireana y la educación permanente en la práctica cotidiana.

Durante este momento histórico tan duro y complejo que requiere todo nuestro compromiso colectivo y nuestros recursos intelectuales y personales, y en la ocasión de estas dos efemérides, es un enorme placer e inspiración imaginar la presencia de Freire en Valencia y honrar su memoria, y cómo esta memoria sigue siendo reinventada a través de nuestras experiencias vividas. De manera sencilla, pero también sinceramente, concluyo estas palabras en homenaje a Paulo Freire para decirles a mis colegas de allí y a quienes en cualquier lugar del mundo puedan estar leyendo este importante número, a luta continua.

Lauren Ila Misiaszek Beijing, China/Nagoya, Japón

Profesora Asociada, la Universidad Normal de Beijing Directora Asociada, Instituto Paulo Freire, UCLA Secretaria General, Consejo Mundial de Sociedades de Educación Comparada [2016-2019] Hija internacional no. 43, escuela de la vida de Sra. Marite Oller Escuder 


\title{
De Angicos [Brasil, 1963] a Valência [Espanha, 1995] para o mundo - Paulo Freire: um legado de esperança
}

\author{
Maria da Salete Barboza de Farias [MPPGAV/MPPGOA/UFPB/Brasil] \\ Adriana Valéria Santos Diniz [MPGOA/MPPGAV/UFPB/Brasil]
}

No dia 14 de setembro de 2020, tivemos a grata satisfação de receber um convite do professor José Beltrán Llavador para enviar uma breve saudação internacional, a ser incluída na magnífica iniciativa da Universidade de Valência [UV], que procurou dar vida a dois acontecimentos históricos: de um lado, para a educação em geral e de outro, para a educação de adultos, por meio da celebração/homenagem dos $100^{\circ}$ aniversário de nascimento de Paulo Freire e dos 25 anos de sua presença na Conferência na Universidade Internacional Menéndez Pelayo [UIMP], em Valência, onde proferiu a palestra inaugural "a importância estratégica da Educação de Adultos", cujo conteúdo é o carro chefe desta publicação.

Embora a homenagem por si só seja um ato educativo, que se realiza através de uma revista científica - Creativity and Educational Innovation Review [CEIR], reveste-se de importância ímpar para o mundo, na medida em que o jogo das letras, imagens e palavras na pedagogia freireana, extraídas do cotidiano, possibilitou muitos jovens e adultos viver mais plenamente a sua condição humana. Assim, saudamos a iniciativa da Universidade de Valência!

Pensar em Paulo Freire, este grande educador brasileiro, nos traz à memória a exitosa experiência de educação de adultos em Angicos, Rio Grande do Norte [RN], no nordeste do Brasil, em 1963 - que ficou conhecida mundialmente como "quarenta horas de Angicos", pelo fato inédito de ter conseguido alfabetizar 380 trabalhadores nessa curta extensão de tempo. Esta ação não se limitou a fazer o sujeito ler e escrever palavras, mas 'ler e escrever o mundo', a partir do conhecimento dos alunos, instigando no jovem, no adulto, a sua capacidade de pensar, de criar, de recriar saberes. Como Freire [1987, p.68] mesmo dizia sabiamente: "Não há saber mais ou saber menos: há saberes diferentes". A notoriedade da metodologia freireana reside no fato de que ela transcende a luta contra o analfabetismo no Brasil, ao lutar pela democracia, inclusão e cidadania.

Paulo Freire reforçou o sentido da educação como ato político, como ato valorativo, cheio de racionalidades, intencionalidades e afetos. A dimensão política do educador se expressa desde a escolha das metodologias, dos materiais, dos conteúdos, dos valores, bem como das concepções de ser humano e de sociedade. Evoquemos os conceitos de educação bancária e educação libertadora em sua celebre obra "A Pedagogia do Oprimido", escrita no seu período de exílio no Chile, em 1968, em sua brilhante crítica ao modelo de educação adotado no sistema capitalista. Para Freire [1970, p.62], "na visão bancária da educação, o saber é uma doação dos que se julgam sábios aos que julgam nada saber". Doação que se funda numa das manifestações instrumentais da ideologia da opressão [...]". O seu contrário, a educação libertadora, é, principalmente, uma educação conscientizadora, uma vez problematizadora da realidade para buscar transformá-la. Nesse processo, educador e educando aprendem NA e COM a realidade, buscando/visando a humanização do mundo, pela construção de uma cultura emancipatória e criadora de realidade[s]. 
Toda essa busca pelo conhecimento e do saber é feita por meio do diálogo entre educador e educando. 0 diálogo torna-se peça fundamental no processo educativo. Ele é uma exigência existencial [..] é o encontro em que se solidarizam o refletir e o agir de seus sujeitos [...] [FREIRE, 1996, 9.78]. É nesse vai e vem de palavras e de práticas que o pensamento de Paulo Freire se agiganta, viaja o mundo, se eterniza. É só relembrar o itinerário de contribuições que ele deixou nos continentes africano, europeu, sul e norte americanos e asiático. Reviver a passagem do educador Paulo Freire por Valência, em 1995, é reviver a sua bagagem libertadora. Com ela, ele se imortaliza, como também se perpetuam a esperança, o amor e o diálogo, tão enfatizado em todas as suas obras.

A Pedagogia da Autonomia [1996], sua última obra publicada em vida, traz com força o resgate da dignidade e da ética como alicerces para as decisões dos sujeitos, no ato de pensar e agir responsavelmente. No cenário atual de destruição dos valores e de acentuação de desigualdades no contexto da pandemia, o educador não pode se eximir de, na sua prática docente, instigar a capacidade crítica dos educandos, o estimulo à solidariedade e à ética, o saber, a escuta e o diálogo, e sobretudo a esperança. Assim, se atualiza o seu pensamento: "o educador se eterniza em cada ser que educa".

A comemoração dos 50 anos de Angicos, no ano de 2013, ensejou todo um movimento políticopedagógico, tanto na cidade, como no Estado do Rio Grande do Norte [RN], como no país e fora dele, envolvendo governos, agentes públicos, universidades acadêmicos, movimentos sociais, diversas organizações da sociedade [como o Instituto Paulo Freire, a Cátedra Unesco da EJA]. 0 Professor José Beltrán foi um dos tantos entusiastas dessa comemoração.

A cidade de Angicos contava, nesse momento, com um índice de analfabetismo adulto tão expressivo como o da época de Paulo Freire, apontando para a necessidade da experiência pedagógica freireana ser vivida para além de uma celebração do passado, mas como inspiradora de um novo futuro para a Educação de Jovens e Adulto [EJA] no Brasil. Uma EJA entendida como um continuum ao longo da vida, não limitada ao processo alfabetizador, mas como um elemento formativo e cultural e não meramente escolar, indutora de um conjunto de políticas públicas tratadas de modo intersetorial, como um projeto de cidadania libertadora, tal e como apregoava Paulo Freire.

Paulo Freire, que tanto notabilizou o pensamento progressista educacional brasileiro, difundido em tantos países e em tão variados contextos, foi também, por sua força, negado e desvalorizado por vários governos brasileiros, foi assim no seu exílio, é assim, na atualidade, quando tornouse alvo de duras críticas do governo de Jair Bolsonaro, que o acusa de doutrinação política dos alunos e responsável pelo baixos resultados da educação brasileira. Freire, ao contrário, fez do diálogo a categoria central do seu pensamento, defendendo o respeito e a diversidade de opiniões.

Paulo Freire é símbolo de resistência, de libertação, de luta pela possibilidade de uma sociedade melhor, mais justa, mais democrática. Ele é, em si, não apenas uma palavra geradora, mas todo um movimento gerador, que nos convida a nos reiventarmos, a nos transformarmos, transformando a educação e o mundo, sendo portadores dessa esperança.

Freire deixa a esperança como um grande legado, faz da esperança um verbo: esperançar. É preciso ter esperança, diz ele, mas ter esperança do verbo esperançar; porque tem gente que 
tem esperança do verbo esperar. E esperança do verbo esperar não é esperança, é espera. Esperançar é se levantar, esperançar é não desistir esperançar é construir!

João Pessoa, Paraíba, Brasil - Praia do Bessa, outubro de 2020.

\section{Referencias:}

Freire, Paulo. Pedagogia da Autonomia - Saberes Necessários à Prática EducativaEditora Paz e Terra. Coleção Saberes. 1996

Freire, Paulo. Pedagogia do Oprimido. São Paulo: Paz e Terra. 1996. p 57-.77

Freire, Paulo. Pedagogia do Oprimido. 17ª ed. Rio de Janeiro, Paz e Terra, 1987. [1 ${ }^{a}$.ed.1970] 


\section{Carta de indignação e esperança [ao mestre Paulo Freire]}

\section{Uyguaciara Veloso Castelo Branco}

Esse texto é um misto de amor, indignação e esperança, parafraseando Ana Maria Araújo Freire [2000], a companheira Nita, que resumiu todo seu amor e dedicação ao nosso Patrono Paulo Freire e registrou lindas e doces palavras, prefaciando a obra Pedagogia da Indignação, publicada em 2000, após sua partida entre nós, em 1997.

Freire escrevia movido pelo amor e crença na democratização da sociedade, sem perder de vista a relação dialética entre indignação e esperança e nunca precisamos tanto mobilizar nossas melhores energias de indignação frente à realidade arbitrária e injusta em que vivemos, porém sem perder de vista a utopia do verbo esperançar, tão caro ao nosso patrono! E não há nada mais poético do que traduzir a esperança em ação, em prática... Afinal, como diz Freire [1978, p. 76], nossa esperança deve ser uma forma ativa e criativa de agir no mundo, na vida, com o outro:

\footnotetext{
Não de uma falsa esperança, que é a de quem espera na pura espera, por isso que vive um tempo de espera vã. A espera só é esperançosa quando se dá na unidade entre a ação transformadora do mundo e a reflexão crítica sobre ela exercida.
}

Em tempos de "distanciamento social", não podemos perder o sentido humanitário do nosso fazer docente, do nosso fazer no/para o mundo, mas para que as nossas ações se traduzam em esperança, para nós mesmos e para o outro, precisamos manter a nossa capacidade de indignação frente às injustiças sociais, às desigualdades e todas as formas de discriminação, hostilidade e exclusão. Temos que ser intolerantes, radicalmente intolerantes a toda forma de pensamento, ação ou reação que tente tolher nossa dimensão humanitária, solidária e política! Pautados pela indignação vigilante e ativa, podemos construir nossa práxis de esperança, prospectando uma sociedade melhor e mais justa, movidos pela energia do fazer coletivo, aguerrido e austero, sem perder a leveza do sonho como projeto de vida, construído em nosso fazer diário!

E esse sonho, movido por indignação, intolerância vigilante, amor pelo fazer docente em sua plenitude e esperança pujante é fruto de um trabalho árduo, competente, brilhante e engajado do mestre Paulo Freire, responsável por uma geração de educadores e educadoras inquietos/as, engajados/as, indignados/as e profundamente esperançosos/as, formados/as e forjados/as pela sua trajetória militante... Por isso, os sonhos de que nos fala Freire [2000] são projetos de luta, são atos políticos de superação de obstáculos, com avanços e retrocessos, em constante enfrentamento com os projetos políticos dos opressores, os contra-sonhos hegemônicos.

Sonho e realidade permanecem em constante embate, em conflito, em luta permanente e histórica entre a transformação e o conservadorismo, contraditoriamente presentes em todos os momentos históricos que vivemos. Assumimos, para isso, como opção política progressista, a luta em favor da vida, da justiça, da equidade, do respeito à diversidade. Adotamos, igualmente, a intolerância radical e a indignação pela morte, pela injustiça, pela negação da opressão, da diferença e do preconceito, quaisquer que sejam as formas assumidas na sociedade, veladas ou explícitas. 
Realmente é compreensível o ódio sentido por essa legião de iletrados, que tenta emergir do lodaçal de sua mediocridade e toma conta da política não apenas em nosso amado país, mas de partidos políticos ultrarradicais de direita em todo o mundo! Eles possuem ojeriza ao pensamento crítico e, por isso, precisam odiá-lo mesmo porque você, Mestre Paulo Freire, é o nosso farol a iluminar nossa prática e nos encher de esperança histórica em dias mais promissores e, enquanto esses dias não chegam, lutemos em nossas searas, manifestando um humanismo indignado e vigilante e a convicção histórica e cultural de que a transformação [transform-ação], dialeticamente, está presente na ação: "A mudança é uma constatação natural da cultura e da história. 0 que ocorre é que há etapas, nas culturas, em que as mudanças se dão de maneira acelerada." [Freire, 2000, p. 16).

Porém, a lâmina da História que atinge os acontecimentos não é inexorável, até mesmo aos que querem congelar o tempo e darem a dimensão de permanente, assumindo uma posição fatalista e atribuindo poder determinante, para um dado acontecimento social, político, educacional etc., negando-lhe sua dimensão perecivel ou seus condicionantes históricos, que nos permite ver a História como tempo de possibilidades, problematizando o presente, o passado e o futuro.

A eles, aos sujeitos atemporais, aos fatalistas deixo-lhes um lindo recado poético, que apresenta resistência e enfrentamento desde o seu título:

\author{
Poeminha do Contra \\ Todos estes que aí estão \\ Atravancando meu caminho, \\ Eles passarão. \\ Eu passarinho! \\ [QUINTANA, 2005, s.p.]
}

E, enquanto eles rastejam, presos ao real congelado, coisificado que construíram em suas visões simplistas, nós educadores voamos com nosso mestre Paulo Freire, porque compreendemos e vivenciamos, em nossa prática, que aprender a ler e a escrever nos permite ler e reler o mundo com os olhos de um tarefeiro, que se descobre, se engaja, aprende, compreende e se liberta da subordinação e da dependência a que foi, ideologicamente, convencido a obedecer, de maneira mecânica. Entendemos que "o futuro não nos faz. Nós é que nos refazemos na luta para fazê-lo." [Freire, 2000, p. 27].

Somos forjados na luta, no fazer-refazer diário, na resistência, na rebeldia revolucionária diante das pseudo-certezas e injustiças, acreditando que a mudança é possível e deve estar pautada nas nossas ações político-pedagógicas. É o que Freire [2000, p. 39] nomeou de psico-análise histórico-político-social que a alfabetização adquire quando consegue libertar o oprimido da figura do opressor que introjetou, substituindo-a pela autonomia e responsabilidade, ultrapassando a leitura da palavra e adentrando à leitura do mundo.

Nesse sentido, o caráter inacabado, impermanente, inconcluso do ato de educar e de aprender possui a mesma matriz da esperança, a matriz da busca incessante do que é difícil de ser feito, mas é possível e, por isso, "enquanto presença na História e no mundo, esperançadamente luto pelo sonho, pela utopia, pela esperança, na perspectiva de uma Pedagogia crítica. E esta não é uma luta vã." [Freire, 2000, p. 53]. 
E, assumindo nosso compromisso político-pedagógico, reafirmamos que essa luta é nossa, enquanto educadores comprometidos com o sonho e a esperança em ação, aliando ao nosso fazer cotidiano um discurso transgressor, em defesa da autonomia, contra a opressão, o arbítrio e a negação da liberdade.

\section{Referencias:}

Freire, P. [1978]. Cartas à Guiné-Bissau: registros de uma experiência em Processo. 2 ed., Rio de Janeiro, Paz e Terra.

Editora UNESP.

[2000]. Pedagogia da Indignação. Cartas pedagógicas e outros escritos. São Paulo:

Quintana, Mario [2005]. Mario Quintana: poesia completa. Rio de Janeiro: Nova Aguilar. [Org. Tânia Franco Carvalhal] 


\section{É tempo de travessia: diálogos com Paulo Freire}

\section{Edna Gusmão de Góes Brennand - UFPB/Brasil}

Ao realizar esse evento comemorativo, a Universidade de València fomenta reflexões sobre a educação cujas raízes possui implicações importantes nas ideias de Paulo Freire, cujo pensamento continua inovador e atual. Mesmo em tempo de crise, a Educação continua a ser uma ferramenta importante para a transformação da sociedade, ajudando às pessoas a se reeducarem através da travessia.

Esta saudação ao educador tem um sentido importante em função da crise multidimensional, de ampla envergadura sanitária, humanitária, política e econômica trazida pela COVID-19. A Universidade de València lança sobre nós uma lufada de ar fresco, propondo uma saudação internacional a Paulo Freire, por ocasião de 25 anos da conferência do autor em València [1995], e o centenário do seu nascimento [1921]. O convite a mim enviado pelo professor José Beltrão para participar desta saudação resvalou o meu olhar das estatísticas cotidianas sobre a Pandemia do Sars Covid-19 [Coronavírus] para sentir, mais uma vez bem perto, a ideia que Paulo Freire deixou para os educadores do mundo: inspirar em jovens e adultos a educação como prática de liberdade. Estamos vivendo um tempo de crise da utopia. Reafirmá-la constitui-se em um ato pedagógico essencial, na construção da educação no "novo normal" pós-pandemia.

Nesse contexto de insegurança e perplexidade, o sentido da vida, da relação das pessoas com a morte, a importância do luto e de ritos culturais de experimentação destes, expõe uma crise de valores sem precedentes. Desde os primeiros contágios pelo Coronavírus, em todo o planeta, assistimos de forma recorrente, em todos os espaços midiáticos, que os "sujeitos" desta história aparecem diluídos em tabelas numéricas e associações estatísticas de morte e sobrevivência. A vida vem adquirindo um caráter mais complexo do que simplesmente resolver o problema do acesso a um tratamento específico, e as escolhas médicas para quem deverá ter prioridade para sobreviver ou morrer. A relação entre fé e ciência retorna à discussão, e a mídia mundial mostra, de forma teatral, a corrida em busca de uma "verdade universal" e de validação para o conhecimento científico. A ênfase dada à luta pela vida e a busca de uma vacina para o combate ao vírus empurram os países a um frenesi de atividades científicas, na formação de bancos de dados, na grande maioria das vezes, sem diálogos com os contextos sociais nos quais estes foram gerados. A extrema urgência da luta pela vida e os múltiplos contextos de sofrimento social estão levando a um certo esvaziamento das esferas reflexivas, e a capacidade de reconfiguração metafórica sobre o destino dos seres humanos. Estamos assistindo à uma necessidade impreterivel de ações coletivas globais e o debate sobre estados transnacionais, no sentido de concertar e diminuir os efeitos desta pandemia sobre a vida humana, a estrutura econômica e o já sentido esgarçamento social. Nesse contexto, a educação encontra-se sem rumo certo, diante das narrativas que construíam seus pilares: profissionalização, regulamentação das relações de 
trabalho, emprego e inovação, formação para a cidadania. Dados oficiais da UNESCO ${ }^{9}$ apontam que cerca de 1,5 bilhão de alunos e 60,3 milhões de professores de 165 países foram afetados pelo fechamento de escolas, em função da pandemia. Sinaliza que uma importante queda na aprendizagem deverá perdurar por mais de uma década se os governos, sobretudo nos países em desenvolvimento, não investirem em melhorias de infraestrutura, tecnologias, formação, metodologias e salários, reforço alimentar, tutoria fora do horário usual das aulas e material didático adicional.

As soluções buscadas via educação a distância não têm dado conta da complexidade de realizar educação de forma remota, em um mundo pautado na desigualdade de acesso à conectividade de internet e à educação de qualidade. A equidade passa a ser uma preocupação global, mas, antes da pandemia, seus reflexos já apontavam que ela permeava somente os discursos da educação para todos. Paulo Freire já denunciava, desde a década de 70, que o acesso a conteúdos relevantes para formação cidadã era desproporcional para os estudantes vulneráveis e desfavorecidos, que dependem das escolas tanto para a formação para o trabalho, para a cidadania, bem como serviços de saúde e nutrição. Se tais aspectos já eram precários antes da crise para determinados estratos da população, tais como imigrantes, negros, mulheres, pobres e deficientes, com o fechamento de escolas essa rede de segurança vital e apoio emocional se esgarça de forma significativa. Embora seja possível registrar um esforço de coalizão global com parcerias do setor privado, incluindo, Microsoft, GSMA, Weidong, Google, Facebook, Zoom, KPMG e Coursera, e os parceiros multilaterais, incluindo a Organização Internacional do Trabalho, o Alto Comissariado da ONU para os Refugiados, o Fundo das Nações Unidas para a Infância, a Organização Mundial da Saúde, o Programa Mundial de Alimentos e a União Internacional de Telecomunicações, bem como a Parceria Global para a Educação, a Education Cannot Wait, a Organização Internacional da Francofonia, a Organização para a Cooperação e Desenvolvimento Econômico e o Banco de Desenvolvimento Asiático etc., os frutos ainda não são perceptíveis. Entretanto, tem sido um grande desafio articular este momento de crise e coalizão com o que advogava Paulo Freire em sua Pedagogia da Esperança ${ }^{10}$. Para Freire, a educação em nenhum momento histórico, deixará de ser uma aventura desveladora, uma experiência de desocultação da verdade. Não é possível entender a existência humana sem esperança e sem sonho, pois a esperança é necessidade ontológica. A desesperança nos imobiliza e nos faz sucumbir ao fatalismo, e neste não há como juntar as forças indispensáveis ao embate recriador do mundo. Diz, ainda, que não é possível o embate sem levar em consideração os dados concretos e materiais, uma vez que a esperança é necessária, mas não suficiente, ela sozinha não pode ganhar a luta, mas sem ela a luta fraqueja. Freire reconhece que a solidariedade é a forma de luta que pode permitir a instauração de uma ética universal, e esta deve ser o fundamento da busca dialogada, em nível mundial, de saídas para a educação do futuro.

Importante e necessária a reflexão sobre a nova normalidade da educação que nos aguarda após a pandemia, sobre as coalizões possíveis, na prática, para assegurar o retorno aos princípios norteadores de uma educação como prática de liberdade, como advoga Freire ${ }^{11}$.

$9 \quad$ UNESCO. A Comissão Futuros da Educação da Unesco apela ao planejamento antecipado contra o aumento das desigualdades após a COVID-19. Paris: Unesco, 16 abr. 2020. Disponivel em: https://pt.unesco.org/news/ comissao-futuros-da-educacao-da-unesco-apela-ao-planejamento-antecipado-o-aumento-das. Acesso em: 4 jun. 2020.

10 FREIRE, P. Pedagogia da esperança: um reencontro com a pedagogia do oprimido. São Paulo: Paz e Terra, 2010

11 FREIRE, Paulo. Educação como prática da liberdade. 14 ed. rev. atual. Rio de Paz e Terra, 2011. 
Poderemos, em seu pensamento, buscar bases epistemológicas para a construção deste novo normal educacional, trazido após a pior crise de saúde em um século. 0 tema da equidade social não pode mais ser pensado a partir de suposições ingênuas, de dados ausentes, e, sobretudo, abordando questões, de longa data, relacionadas à desigualdade estrutural, à pobreza e à exclusão. Não se pode prescindir, neste momento, de uma esperança que tem como pedra angular a ética e os direitos humanos. Seu fundamento ético-histórico pode fazer do processo político de reconstrução da educação pós-pandemia um processo pedagógico amplo, em que todos os sujeitos da luta busquem a equidade pela minimização das injustiças, dos abusos, dos individualismos e do tráfico de influência, construindo novas tramas com novos saberes.

As experiências de diálogo que estão sendo construídas neste momento de crise, entre atores governamentais e sociedade civil, podem buscar o sentido ontológico do diálogo na perspectiva frereana, ou seja, enquanto elemento necessário para o reconhecimento da diversidade, para o aprendizado e para a construção de um futuro melhor para os seres humanos. Defende que uma ação dialógica deve ser fundada na colaboração, no aprendizado mútuo, no compartilhamento de um objeto cognoscivel a ser compreendido e que, no processo, permita a compreensão e a valorização das diferentes realidades. Entendemos que esta concertação global é um espaço privilegiado para que todos os países, e seus diferentes contextos sociais, possam ser desvelados. 0 diálogo no sentido frereano pode fazer emergir fatos novos, novas perguntas, cujo conhecimento anterior não dão conta de responder, novos horizontes, novas partilhas cognitivas. Freire reconhece que não existe diálogo em vácuo político, que este não é um espaço livre onde se diz o que quiser. Para haver diálogo, argumenta, é necessário programas, objetivos e contextos. Objetivos de transformação, responsabilidade, direcionamentos, determinação e disciplina. Necessário dialogar a partir de pontos de partida concretos e de horizontes de chegada bem delineados. Sem o exercício do diálogo, a busca de soluções educativas estará fadada a decisões monocráticas de governos. Ao dizer suas palavras, ao chamar ao mundo para ser interpretado, os sujeitos sociais o transformam. Nesse processo, o diálogo impõe-se como uma necessidade existencial. No diálogo interinstitucional, no diálogo entre países e no diálogo nas instâncias civis das sociedades, vemos a instauração da conexão epistemológica em relação aos estudos e pesquisas sobre o Coronavírus. Este objeto, ainda com muitas nuances, a serem desveladas está vinculando sujeitos cognitivos, levando-os a refletir, juntos, sobre suas implicações sobre a vida. Leva para a cena mundial um conceito de aprendizagem que Paulo Freire reflete ao longo de suas obras. Ele se fundamenta na certeza de que não é mais possível a transferência de conhecimento entre que faz a pronúncia do mundo e quem recebe a dádiva do conhecimento [educação bancária]. Aprender requer uma aproximação dinâmica entre diversos saberes, acionando a inteligência coletiva fundada na visão frereana de bases humanista e globalista. Estamos assistindo e participando do que Paulo Freire denominava de diálogo e conflito. Para ele, a conflito não pode se tornar obstáculo na busca de soluções a problemas comuns, é preciso buscar sua dimensão pedagógica que desenvolve e favorece o desenvolvimento da aprendizagem de valores e regras. 0 desafio para a busca de uma vacina tem aproximado países, redes de pesquisadores e governos que, minimizando conflitos anteriores, trabalham agora em conjunto. Ao fazê-lo, tornam-se educadores, desencadeando a combinação de autoridade e respeito mútuo.

Estamos enfrentando determinantes sociais de diversas ordens, e, nesse contexto, na esteira desta luta, a educação precisa ser repensada. As análises realizadas por todos os países apontam efeitos diretos no processo educativo e nas atividades pedagógicas em todos os níveis de ensino, decorrentes da interrupção das atividades presenciais. As novas formas de socialização de crianças, jovens e adultos com a duração prolongada do confinamento, a falta de contato pessoal 
com os colegas de classe, o medo da infecção pelo vírus, o espaço da casa transformado em sala de aula etc. ainda requerem compreensão mais aprofundada. Mesmo considerando que a educação remota tenha limitações em função do acesso diferenciado às tecnologias pelas populações mais vulneráveis, e assimetrias no acesso à internet, não podemos prescindir da reflexão de que a educação, mesmo mediada pelas tecnologias digitais, deva-desenvolver diálogos pedagógicos não lineares. Defendida por Paulo Freire, a educação emancipatória não pode ser mecânica, isenta de consciência do mundo, sem imersão na realidade. A educação como ato político age diretamente sobre a realidade social. Assim, ocorrendo na modalidade remota ou presencial, o direito à educação de qualidade para todos precisa estar no centro dos debates sobre o novo normal. A concepção de educação crítica deverá permear currículos e programas. Mesmo nos novos suportes virtuais ela pode se desenvolver com o compromisso de tornar-se uma educação para a liberdade e para a autonomia, e que tenha conteúdos problematizadores e significativos. Que estes conteúdos não sejam massificados, mas propiciem um olhar crítico sobre a realidade, permitam fomentar a curiosidade constante que Freire considera primordial para o desenvolvimento cognitivo humano. Para isso, os docentes devem ser preparados para desenvolverem atividades pedagógicas sempre com o intuito de iluminá-las criticamente a partir das reflexões contemporâneas, ensinando a transgredir as naturalizações que embotam a capacidade crítica e o desenvolvimento cognitivo, bem como a capacidade reflexiva de contribuir para lidar com a diversidade. A educação remota deve propiciar o olhar para o dinamizar da vida, e não apenas concebê-la de forma estanque e automatizada.

Ao longo de sua atuação como educador em diversos países e culturas, bem como em sua obra, é possível registrar a forma como Paulo Freire realizava conexões permanentes entre um tempo e uma sociedade. Reconhecia que vivenciava embates com seus valores, com sua forma de ser e estar no mundo, mas sempre sentia a necessidade de convidar docentes e alunos, e pensar o outro que estava por vir, na possibilidade de que a educação fosse uma via para o configurar-se permanentemente. Esse convite, nos dias atuais, necessita ser aceito por todas os atores do processo educativo, seja formal ou informal. Ao pensar a educação presencial alguns buscam permanência, já outros buscam novos rumos para os enfrentamentos, para estabelecer novas realidades. A proposta educacional de Freire traz luzes sobre possiveis rumos da educação pós pandemia. Estas luzes podem iluminar novos caminhos para os que buscam a educação como prática de liberdade, e também abrir horizontes para os que ainda estão entrincheirados sob o domínio do medo e/ou a busca por privilégios. Para Freire, não existe um modelo único, capaz de tornar exitosa a ação educativa. Se realizada de forma remota ou presencial, a educação deve refletir, segundo Freire, a luta contra a acomodação e o ajustamento. Deve propiciar a tomada de consciência das situações de risco em que se encontra a sociedade.

É tempo de travessia e a educação como prática de liberdade fomenta esperanças da da possibilidade de reconstrução de uma educação aberta e transformadora. Paulo Freire! Presente! 


\section{Paulo Freire: genialidade na simplicidade}

\section{Elda Silva do Nascimento Melo}

O que dizer sobre Paulo Freire que ainda não foi dito?

Uma tarefa realmente difícil, pois Paulo Reglus Neves Freire foi um educador e filósofo notável. É o pensador brasileiro mais reconhecido mundialmente, tendo sido um grande influenciador na história da pedagogia, inclusive contribuindo inexoravelmente para a difusão da pedagogia crítica. Nos tempos atuais, influencers digitais alcançam milhões de seguidores, em suas redes digitais. Entretanto, Paulo Freire como é mais conhecido, mesmo na era analógica, conseguiu influenciar várias gerações de educadores, impactando os processos formativos e a compreensão do currículo como uma oportunidade de romper com a educação bancária e a promoção de uma educação libertadora fundada na prática dialógica e nos princípios democráticos.

Freire possuía muitos atributos que o fizeram se destacar nas diversas áreas da educação. No Brasil, ganhou notoriedade especialmente quando propôs alfabetizar um grupo de 300 adultos trabalhadores em 40 horas.

Angicos é uma cidade pequena do Rio Grande do Norte, no Nordeste do Brasil. Nesta cidade, Paulo Freire implementou um projeto de alfabetização conhecido como "Quarenta horas de Angicos". Por meio desse projeto, Freire alcançou dois objetivos: primeiro, demonstrou que era possivel promover a leitura das palavras, a partir da leitura de mundo dos aprendentes; segundo, evidenciou que a educação pode ser um instrumento de libertação e conscientização acerca da condição de opressão a qual os indivíduos são submetidos.

Para Freire [2005], as palavras geradoras, não devem ser estabelecidas aleatoriamente pelo educador, mas devem ser buscadas na existência concreta do alfabetizando, em sua relação social com outros seres humanos mediatizadas pelo mundo.

A ideia de alfabetizar a partir do campo semântico que permeia o cotidiano, ou seja, a realidade objetiva dos sujeitos foi de fato bastante inovadora. 0 rompimento com a hierarquia entre professor e aluno e a apologia ao diálogo denotava uma revolução na educação tradicional e conservadora. Advogava Freire que "O diálogo é esse encontro dos homens, mediatizados pelo mundo, para pronunciá-lo, não se esgotando, portanto, na relação eu-tu.” [FREIRE, 2005, p. 91]).

Por essa iniciativa e por suas ideias revolucionárias Paulo Freire sempre provocou reações polarizadas. Educadores progressistas encontravam e encontram ainda hoje, eco em suas palavras; enquanto governantes que apostam na ignorância como forma de manter o status quo, o acusam de ser uma "praga comunista". Ou seja, para além de revolucionar o como fazer no âmbito da alfabetização de adultos, especialmente, ainda trouxe para a educação um viés político-ideológico que levava os educandos a se identificarem e se conscientizarem acerca de sua condição de oprimido em anuência aos opressores.

Essa polarização fica patente quando examinamos a história de Paulo Freire. Seu método 
revolucionário voltado para a alfabetização e a educação popular, foi reconhecido pelo governo do presidente João Goulart [1964], que tentou aplicar essa experiência em todo o país, por meio da instituição do Plano Nacional de Alfabetização. No entanto, poucos meses após a sua implantação, o plano foi vetado pelos militares, que assumiram o governo. Freire foi preso por 70 dias e depois expulso do país. Passou 16 anos em exílio. Durante esse tempo viajou por vários países como Chile, Suíça, Estados Unidos e Inglaterra e difundiu sua metodologia de ensino em países africanos de como Guiné-Bissau e Cabo Verde.

Em 1969, Paulo Freire lecionou na Universidade de Harvard. Durante dez anos, foi consultor especial do Departamento de Educação do Conselho Municipal das Igrejas, em Genebra, na Suíça. Por seu trabalho na área educacional, Paulo Freire foi reconhecido mundialmente. Ele é o brasileiro com mais títulos de Doutor Honoris Causa de diversas universidades. Ao todo são 41 instituições, entre elas, Harvard, Cambridge e Oxford.

Em 1980, com a anistia, Paulo Freire retornou ao Brasil, estabelecendo-se em São Paulo, onde foi professor da UNICAMP e da Pontíficia Universidade Católica - PUC, além de atuar como Secretário de Educação da Prefeitura de São Paulo.

Em 2012, foi declarado Patrono da Educação Brasileira, por meio da Lei Federal n. 12.612, de 13/4/2012. Essa declaração ocorreu no âmbito do governo da presidenta Dilma Rousseff, filiada ao Partido dos Trabalhadores, de ideologia esquerdista. Entretanto, no governo atual do presidente Jair Bolsonaro, Paulo Freire volta a ser atacado e desqualificado, sob a defesa de que era comunista e doutrinador.

Na contramão dessa assertiva, Paulo Freire sempre defendeu o diálogo e a pluralidade de opiniões. Sua genialidade residia na capacidade de dizer de forma simples ideias complexas e inovadoras, de transcender o lugar comum e formular conceitos pertinentes a realidade social vivenciadas nos espaços escolares e não escolares, em situações educativas. Desse modo, Freire afirma [1997, p. 160] "A alegria não chega apenas no encontro do achado, mas faz parte do processo da busca. E ensinar e aprender não pode dar-se fora da procura, fora da boniteza e da alegria".

Suas formulações demonstravam rigor conceitual, ao mesmo tempo em que evocava a sensibilidade e afetividade. Ademais, reconhecia e atribuía à educação um lugar primordial para leitura do mundo e transformação da realidade. Para o autor, "Se a educação sozinha não transforma a sociedade, sem ela tampouco a sociedade muda" [FREIRE, 2000, p.67].

Paulo Freire fazia eclodir em seus escritos a necessidade de interação e protagonismo dos educandos, levando à reflexão, à problematização e ao desvelamento do lugar que cada um e cada uma ocupa na teia social. Ressaltava que "Ensinar não é transferir conhecimento, mas criar as possibilidades para a sua própria produção ou a sua construção" [FREIRE, 1997, p.47].

Com sua simplicidade, Paulo Freire evidenciava a importância da mediação didática, para além da visão instituída que considerava o professor como o único detentor do conhecimento e que iria imprimir em seus alunos, tábulas rasas, o conhecimento universal, ignorando os conhecimentos prévios e a realidade objetiva. Portanto, para ele "Ninguém educa ninguém, ninguém educa a si mesmo, os homens se educam entre si, mediatizados pelo mundo" (FREIRE, 2005, p.68). Ou seja, alunos e professores devem ser ativos na busca pela aprendizagem, embora exercendo papéis diferentes nesse processo. 
Enfatizava ainda, a perspectiva de formação permanente se colocando como ser inacabado, em construção, um eterno aprendente. Nesse sentido, asseverava que "Ninguém ignora tudo. Ninguém sabe tudo. Todos nós sabemos alguma coisa. Todos nós ignoramos alguma coisa. Por isso aprendemos sempre" [FREIRE, 1989, 39].

Paulo Freire nos ensinou a ter uma atitude dialógica, que permita a reflexão crítica dos homens e das mulheres em suas relações com o mundo para sua libertação, a crítica à educação bancária; a necessidade de o professor ser pesquisador; a problematização e a interdisciplinaridade no ato educativo e a promoção de ciência sensivel às necessidades populares. Enfim, seu legado é atemporal e traz elementos fundamentais, pautados na criticidade e que lança as bases para uma educação de fato libertadora.

Paulo Freire não foi, ele é e permanecerá sendo um estudioso que ensinou a pensar: de forma plural a realidade singular e popular; de forma simples contextos tão complexos; de forma científica, um cenário empírico de senso comum; de forma macro, situações tão micro; de forma afetiva e sensível, realidades tão áridas; de forma crítica, política e analítica, um contexto desprovido de atenção e, finalmente, de forma tão genial a educação em suas mais variadas dimensões, fragilidades e potencialidades.

Por tudo isso, Paulo Freire segue presente nos estudos e reflexões sobre a educação um século depois de seu nascimento. Por tudo isso, suas ideias são atemporais. Por tudo isso, Paulo Freire permanece imortal!

\section{Referências}

Freire, Paulo. A importância do ato de ler: em três artigos que se completam. São Paulo: Autores Associados: Cortez, 1989.

Pedagogia da Autonomia. Saberes necessários à prática educativa. 34.ed. São Paulo: Paz e Terra, 2006.

Pedagogia da indignação: cartas pedagógicas e outros escritos. Apresentação de Ana Maria Araújo Freire. Carta-prefácio de Balduino A. Andreola. São Paulo: Editora UNESP, 2000.

Pedagogia do oprimido. 46.ed. Rio de Janeiro: Paz e Terra, 2005. 


\title{
Freirean reinvention and hope to construct teaching to save Earth: Ecopedagogy
}

\author{
Greg William Misiaszek [Beijing Normal University [BNU]; Paulo Freire Institute, UCLA]
}

Deconstructing, or rather critically reading, the World's politics was Freire's educational goal for praxis to emerge from unlearning and countering ideologies that systematically sustain/ intensify hegemony within and between local-to-global spheres. This brief writing discusses how ecopedagogy, as reinventions of Freirean Pedagogies, widens teaching to the planetary sphere and provides possibilities of transformative environmental pedagogies to save the world and Earth. His book Pedagogy of the Oppressed [1970] written over five decades ago is, unfortunately, as descriptive of current times as when he wrote it, as globalization from above intensifies sociohistorical oppressions such as coloniality, racism, gendering, xenophobia, neoliberalism, and anthropocentricism. Intensifying post-truthism globally has resulted in systematically teaching denial of inconvenient truths such as global warming and, currently, COVID-19 (Misiaszek, 2020a]. Cynicism can certainly arise from my analysis here, frequently leading to fatalism. However, Freire's work until his untimely death in 1997 constructs teaching with/for hope and utopianism to counter fatalism in education that normalizes oppressions and violence without possibilities of opposing counteractions [Teodoro \& Torres, 2007). Freire's (1970) arguments of us [i.e., humans] as unfinished beings [the only "beings" within Nature as such] constructed the foundations of his [re]humanizing education that teaches through students' dreamt possible utopias and determined deepened and widened praxis toward achieving them by critically deconstructing the barriers [or Freire-termed "limit situations"] to achieve the utopian goals.

Freire's influence on in/non/formal education centering social justice is incalculable, with reinvention of his pedagogy for praxis to end planetary devastation caused by us within and between local-to-global spheres is essential [Gadotti, 2008; Misiaszek, 2015]. Reinventing Freire's work, as he argued for his and all pedagogical work to be contextually reinvented, allows for necessary adaption to our and our societies'/populations' unfinishedness towards ending oppressions, violence, social justice, and the intersectionalities between them (Freire, 1970, 1992, 2004]. Ecopedagogy adds the following two more to centralize: environmental justice and planetary sustainability. Both are inseparable from social justice and the later cannot be achieved without valuing the rest of Nature beyond anthropocentric lenses (Misiaszek, 2018, 2020b). As Freire wrote that "[c]ritically reading the world is a political-pedagogical doing" [2004, p. 18], ecopedagogy is reading the world within the rest of Earth [i.e. "ecopedagogical literacy").

\footnotetext{
...the notion seems deplorable to me of engaging in progressive, revolutionary discourse while embracing a practice that negates life-that pollutes the air, the waters, the fields, and devastates forests, destroys the trees and threatens the animals. [Freire, 2004, p. 120]
}

Ecopedagogy is not only rooted in reinventions from Freireans, but also from Freire's own work towards the end of his life. His next book was to be on ecopedagogy before his death and the quote above from Pedagogy of Indignation [2004] was an excerpt from, arguably, his unfinished ecopedagogical book [Gadotti \& Torres, 2009; Misiaszek \& Torres, 2019]\}. It is important to note, as Freire's quote above indicates, social [in]justices are inseparable to environmental 
[in]justices, but ecopedagogical reinventions focus on critically understanding the politics of actions upon Nature outside of humans. There almost endless aspects that could be discussed on ecopedagogies, with this brief writing having focused on the Freirean tenets of education as deconstructing the politics of environmental actions, problematizing limiting situations that prevent utopian outcomes with holistic socio-environmental justice and planetary sustainability, and being reinvention-based within concepts of human unfinishness, including his own pedagogies and other scholarship. In short, Freirean teaching is essential for needed radical transformation before we pass the tipping point of Earth's destruction, with hope that we haven't tipped it yet.

Freire, P. [1970]. Pedagogy of the oppressed. New York: Herder and Herder.

Freire, P. [1992]. Pedagogy of hope. New York, NY: Continuum.

Freire, P. [2004]. Pedagogy of indignation. Boulder, CO: Paradigm Publishers.

Gadotti, M. [2008]. What we need to learn to save the planet. Journal of Education for Sustainable Development, 2 [1], 21-30. Retrieved from http://isd.sagepub.com/cgi/ content/abstract/2/1/21

Gadotti, M., \& Torres, C. A. [2009]. Paulo Freire: Education for development. Development and Change, 40 [6], 1255-1267. doi:10.1111/j.1467-7660.2009.01606.x

Misiaszek, G. W. [2015]. Ecopedagogy and citizenship in the age of globalisation: Connections between environmental and global citizenship education to save the planet. European Journal of Education, 50 [3], 280-292. doi:10.1111/ejed.12138

Misiaszek, G. W. [2018]. Educating the global environmental citizen : understanding ecopedagogy in local and global contexts. New York: Routledge.

Misiaszek, G. W. [2020a]. Countering post-truths through ecopedagogical literacies: Teaching to critically read "development" and "sustainable development". Educational Philosophy and Theory, 52[7], 747-758. doi:10.1080/00131857.2019.1680362

Misiaszek, G. W. [2020b]. Ecopedagogy: Critical environmental teaching for planetary justice and global sustainable development. London: Bloomsbury.

Misiaszek, G. W., \& Torres, C. A. [2019]. Ecopedagogy: The missing chapter of Pedagogy of the Oppressed. In C. Torres, A. [Ed.], Wiley Handbook of Paulo Freire [pp. 463-488]. New Jersey: Wiley-Blackwell.

Teodoro, A., \& Torres, C. A. [2007]. Introduction: Critique and utopia in the sociology of education. In C. A. Torres \& A. Teodoro [Eds.], Critique and utopia: New developments in the sociology of education in the twenty-first century [pp. 1-10]. Lanham, MD: Rowman \& Littlefield Publications. 


\title{
Para Paulo Freire e Valência
}

\author{
Talamira Taita Rodrigues Brito ${ }^{12}$
}

Vitória da Conquista/Bahia/Brasil, em 08 de outubro de 2020

\section{"Educação não transforma o mundo. Educação muda as pessoas. Pessoas transformam o mundo. (Freire, 1987, p. 84)}

Este convite feito é considerado por mim uma honra e ao mesmo tempo um presente desafiador! Gostaria de agradecer imenso por essa oferta e espero honrar o convite.

Ao receber a proposta para participar desse conjunto de escritos sobre Paulo Freire em homenagem ao seu centenário e a sua passagem por Valência, fiz uma viagem no tempo de quando entrei na faculdade, com 18 anos de idade e o que aconteceu em minha vida de lá para cá [acabo de chegar nos 45 anos] e como o Paulo Freire me ajudou a construir um olhar afetivo, político e de transformação junto ao meu processo identitário como professora que sou e alfabetizadora de crianças e adultos que fui!

Tomei então para mim a missão de construir uma Carta para Freire, mostrando um pouco de como me afeiçoei a ele.... mas também, ao escrever esta carta, gostaria de evidenciar de que maneira ele e a sua pedagogia nos proporcionou um desafio que é atual até hoje - o de educar pelo amor, pela esperança, pela transformação política nas relações entre os homens e as mulheres junto ao conhecimento e, por consequência, junto as relações de exploração e sujeição do outro junto ao capital.

Assim, as linhas abaixo serão escritas com a intensão de agradecer pela sua passagem e permanência na minha vida, mas também na vida de muitos brasileiros que se forjaram professoras e professores a partir de suas ideias, de suas palavras e de sua esperança...

Freire,

Quando você esteve em Valência, há 25 anos atrás, eu estava cursando Pedagogia pela Universidade Estadual do Sudoeste da Bahia-Brasil, em 1995 - na cidade de Salvador. Estava no segundo ano do curso sendo apresentada à "Pedagogia do Oprimido"... eu tinha uns 20 anos de vida.

Naquele momento mal sabia de sua grandiosidade já reconhecida pelo mundo, conhecia pouco de sua história... não entendia sobre a educação bancária e, o pior de tudo era não poder dizer por aí que quase não sabia nada sobre você, afinal como uma estudante de Pedagogia não conhecia o "Paulo Freire"????!

Os cursos de formação de professores em nosso país têm dessas coisas... Ainda não temos o

12 Professora Titular do Departamento de Filosofia e Ciências Humanas da Universidade Estadual do Sudoeste da Bahia/Brasil. taitadoc@gmai.com ou talamira@uesb.edu.br 
Freire e sua pedagogia como algo obrigatório em nossa formação no início-meio-fim! Creio que posso assinalar que isso fez parte dos resquícios da Ditadura Militar iniciada em 1964 e findada em 1985 em nosso país [pelo menos como ato].

Te esquecer foi o desafio lançado pelo Golpe Militar, apagar os questionamentos lançados por ti sobre a famosa frase "Eva viu a uva"... Quem era Eva? Como, por quem e em quais condições a uva foi produzida e quem lucrou com tudo isso??!!! Precisava ser apagado da memória dos futuros professores!!! A Educação Bancária precisava permanecer mesmo num processo de redemocratização! Afinal, não se muda todos os personagens de uma vez só, ou ainda, não se esquece o passado e suas práticas como se troca uma faixa de rádio - a história nos conta isso! A mudança é também resistência e tensão entre dois ou mais lados! Assim, cheguei em 1994, em meu primeiro ano de Curso de Pedagogia esquecida de você! Mas, creio também, que meus professores de época foram proibidos de você, de ler você, de manter você vivo na história da formação de professores e da educação brasileira!

Voltando para a Pedagogia do Oprimido, eu me lembro como se fosse hoje quando passei as primeiras páginas pelas minhas mãos e sob meus olhos e iniciei a leitura de suas primeiras linhas... "Nossa, ele falava de coisas, que eu de maneira muito simplória, achava muito bom!" Continuei naquela caminhada, ainda acanhada e com problemas de conteúdo... afinal não compreendia muito bem sobre o Marxismo, Reprodução Social ou a Teoria Crítica e tampouco reconhecia sua história de envolvimento com várias comunidades dos estados o Rio Grande do Norte e Pernambuco [seu estado de origem], ou seja, não o conhecia como deveria o ter conhecido!!!

Vinte anos se passaram e posso afirmar que durante anos de minha vida fui negada de me perceber como oprimida, de me perceber como construtora de uma história, da nossa história, de minha história! Isso é uma conclusão muito dura para se defrontar! Mas, precisamos chegar a esse nível de consciência, se quisermos transformar as práticas sociais que nos conduziram até a presente data - principalmente em nosso país.

\section{A leitura do mundo precede a leitura da palavra!}

Ninguém liberta ninguém, ninguém se liberta sozinho: os homens se libertam em comunhão!

\section{A dialógica é a forma de superação das relações hierarquizadas na relação entre educando e educar! Nas relações estabelecidas no mundo!}

Pensar teoria e prática é pensar a práxis... eu não faço diferente do que penso... logo, se questiono o que faço, devo questionar o que penso! Devo superar formas de dominação do outro e de mim mesmo!!

Essas frases, que já se tornaram tão comuns nas vozes de quem te conhece, também carrega consigo a tomada de consciência sobre quem somos e o que verdadeiramente queremos como ato e lado político: ou se pensa na educação como prática pela e para a liberdade ou se pensa na educação como prática subjugadora! De que lado se está??

Ao Tomar conhecimento de sua passagem pela cidade de Valência, fiquei pensando de como foi para você ter conhecido essa encantadora cidade... imaginei também como a cidade te recebeu e como a cidade se dedicou a ficar com um pouco de sua história, com um pouco de sua 
pedagogia, com um pouco de sua resistência e esperança... Isso porque estive como professora visitante da Universidade de Valência há um ano atrás... conheci algumas classes de formação de professores, conheci alguns professores e alguns projetos também...

Nessas reflexões comparativas percebi o quanto a Universidade de Valência abraçou sua Pedagogia. O Projeto Nau Gran, iniciado em 1999 é prova disso!! Tive a linda oportunidade de acompanhar as aulas do Professor José Beltrán nas turmas de Introdução a Sociologia de uma das formações oferecidas aos adultos acima de 55 anos. Um projeto lindo e que se dedica a abrir as portas da universidade para aqueles que gostariam de continuar seus estudos ou até mesmo de iniciar seus estudos e conhecer a universidade melhor! Basta ter o desejo de conhecer mais sobre uma determinada área do conhecimento ofertado pelo Projeto Nau Gran.

Você está tão presente nesse projeto que as páginas 45 e 46 do Livro "El viatge de la Nau Gran" são dedicadas a falar sobre a Esperança, a sua esperança, a partir de seu Livro Pedagogia da Esperança. Ver a mistura de adultos na sala de aula, ouvir suas histórias e trajetórias de vida, escutar que continuar estudando é uma possibilidade de continuar vivo, de se compreender como sujeito da e de sua história, foi perceber materialmente, como sua passagem fora frutífera e rendeu para aquelas pessoas e para mim possibilidades de participar do seu esperançar.

Eu continuo achando que ainda te conhecemos pouco. Como professora de cursos de licenciaturas, que formam professores, continuo indagando sobre o porquê que não oferecemos uma disciplina de caráter obrigatório para estuda-lo. Ofertar seu legado, para que as gerações futuras não te esqueça, é uma forma de resistir ao esquecimento político que insiste em se fazer presentes nos regimes de direita e de extrema direita. Aqui no Brasil temos o Instituto Paulo Freire, temos professores que estudam, que mantém a chama de seu pensamento vivo e continuam produzindo obras a partir das suas. De certa forma, ainda me considero sua herdeira, ainda considero que levo sua marca de liberdade, de esperançar como ato de luta e de resistência para garantir uma educação libertadora, para todos e transformadora do penar sobre a nossa realidade e assim criadora e propulsora de mudanças.

Antes de finalizar, gostaria também de lembrar que certamente, assim como eu, você deve ter se encantado por Valência, pela sua gente, pela sua organização de cidade e pela forma como a universidade de valência procura ser um patrimônio do povo valenciano. Isso é tão bonito de se ver!!!

Um caloroso abraço e, de onde estiver, que esteja torcendo para sermos mais e melhores do que somos!

Esperançar sempre!!!

\section{Referência}

Freire, Paulo. Pedagogia do Oprimido. Rio de Janeiro: Paz e Terra, 1987.

Freire, Paulo. Pedagogia da Esperança: um reencontro com a pedagogia do Oprimido. Rio de janeiro: Paz e Terra, 1992. 


\section{SENTIPENSAR Freire}

[con permiso de Zubiri y Galeano... Y Carroll y Llach]

María-Jesús Martínez-Usarralde. Universitat de València. España

"Lucho por una educación que nos enseñe a pensar y no por una educación que nos enseñe a obedecer"

Sentir Freire es encontrar muchas sombras en muchos árboles para seguir reconfortadas en esta rebelión contagiosa, rabiosamente emancipadora. Árboles diferentes y distintos que se celebran por ser diversos...jArriba las ramas!

Pensar Freire es saber que, con su legado, nos sigue enseñando a mirar.

Pensar Freire es releer 'Pedagogía del Oprimido' y seguir en diálogo con él donde lo dejamos, encarnando un compromiso y encontrando renovadas respuestas ante miradas procuradas por un ecología de saberes y, ahora, frente al trasfondo de la pedagogía disruptiva que inocula la actual pandemia.

Sentir Freire es quitarse los zapatos y caminar descalza, desobediente, con alguna certeza ante el desamparo y viviendo en los otros, también. I amb el somriure, la revolta!

Sentir Freire es conmocionarme siempre, como si de la primera vez se tratara, ante la curiosidad [curiouser and curioser] que brota, espontánea, en Esther, Joan, Inés, Fernando, Gaspar... En cualquier mente infantil en cualquier lugar de la tierra... "Y puedes decirme tú de dónde...?”. De cualquier curiosidad epistemológica de cualquier aprendiz, nace irremediable un proyecto educativo.

Pensar Freire es sentirlo humano, muy humano. Al lado de quien necesitaba ser escuchado pero no le era permitido. De quien no se sentía digno porque naturalizaron lo que consideraban "infortunio". De quien leía orgullosa: "LI-BRO”, "LI-BRE-TA”... "LI-BRE”.

Pensar Freire es quedarse con la esencia. Su esencia, que la hizo nuestra, desde ese profundo amor que sintió al mundo y a las personas que convivimos en él. Un amor armado en lo político [lo personal es político], incontestable y perdurable en todas las generaciones que seguimos su paso.

Sentir Freire es retratarse a una misma cuando me repito, de manera sustentablemente incesante: "no tengo fuerzas para rendirme"... 


\section{El legado de Paulo Freire en la Universidad}

Alumno del Programa La Nau Gran de la Universitat de València desde hace catorce años, he podido ir conociendo detalles del trabajo previo a su puesta en marcha [1999], por parte de las personas involucradas.

Pero la preocupación por la formación de personas adultas, ya era algo que a nivel mundial venía de muy atrás. Un ejemplo claro es el del Filósofo y Pedagogo brasileño Paulo Freire [1921-1997] al que se homenajea en este número de la revista CEIR.

Paulo Freire, desde mediados del pasado siglo, fue difundiendo sus reflexiones sobre la importancia de la educación [con especial énfasis en la alfabetización y formación de los sujetos adultos] dejando un importantísimo legado, de referencia obligada para los interesados en el tema.

Vale la pena ahora recordar su conferencia de 1995, en Valencia, y su enorme repercusión. Cuatro años más tarde, se pone en marcha nuestro programa La Nau Gran como parte del Servei d’Extensió Universitària. Quizá podría pensarse que los ecos de Freire inspiraron el proyecto de Nau Gran en su singladura

En nombre de la Asociación Amigos de la Nau Gran y en el mío propio, agradecer esta oportunidad al equipo de la revista CEIR.

Presidente de la Asociación Amigos de la Nau Gran Miguel Ángel Guillamón Blasco 


\section{Pese a todo, tenemos pequeños oasis de esperanza Jordi Llacer Folch \\ Director del Centro de Formación de Personas Adultas de Albal [Valencia]}

Hace veinticinco años, en 1995, Paulo Freire dio una conferencia en la U. I. Menéndez Pelayo. Hay una frase del pedagogo que no olvido nunca antes de empezar a trabajar con un grupo y que me repito muchas veces para centrar mi labor docente:

Los profesores contestan a preguntas que los alumnos no han hecho. Todos nosotros sabemos algo.

Todos nosotros ignoramos algo. Por eso, aprendemos siempre. [Paulo Freire]

En el aniversario de la visita de Freire a Valencia, no me queda otro remedio que seguir su espíritu crítico y exponer mi punto de vista respecto de la situación de la educación de adultos. En los albores de una ley de FPA del País Valencia, la del año 1995, prometía ser un revulsivo respecto a la educación de adultos. Había sido una ley elaborada con participación de todos los ámbitos educativos: administración, profesorado, alumnos adultos y agentes sociales. Tenía todos los componentes para poder transformar una formación solo técnica en una formación personal y social, teníamos los andamios y las ideas para mejorar nuestra estructura educativa pero... la ley no se desarrolló porque la política cambió y las leyes superiores continuaron con una formación clasista, continuista y sin ningún interés en transformar a la ciudadanía en pensadores demócratas.

Siento que las palabras de nuestro querido Freire, que nos proponían una pedagogía que nos previniera del neoliberalismo, no han conseguido superar desgraciadamente el consumismo. $Y$ el capitalismo que campa a sus anchas en este mundo digital absorbe ideologías y espacios sociales y de formación.

Ni siquiera una pandemia mundial, que nos hizo ver de lo perjudicial de algunas acciones humanas sobre el planeta, han conseguido hacer cambiar el discurso de los medios de comunicación dominados por las multinacionales y las luchas comerciales internacionales.

Pese a todo tenemos pequeños oasis de esperanza hacia la educación liberadora y posiblemente la FPA podría ser una de ellas. Cuando veo la transformación que algunos alumnos y alumnas sufren después de pasar por nuestros centros, me da la impresión, por sus comportamientos, que ellos han cambiado algo en su interior que nos permite tener pequeñas alegrías sobre su futuro, en una nueva integración social que no tenían antes de pasar por las aulas.

Afortunadamente algunas ideas pedagógicas de Freire nos recuerdan que la educación es emoción y transformación. A ellas nos aferramos para convertirnos, a veces, en ciudadanos. 


\title{
Tribute to Paulo Freire Maria del Pilar O'Cadiz
}

\author{
Ph.D., University of California, Los Angeles
}

It is my humble honor to contribute to this centennial celebration of Paulo Freire's extraordinary contribution to humanity, particularly in the city of Valencia, the birthplace of my great-grandmother and a city of which I am very fond of, having visited family there over the years.-Feliç aniversari estimat mestre.

My first encounter with Paulo Freire was reading his seminal work, Pedagogy of the Oppressed [1970], in a Sociology of Latin America class at Oberlin College in 1980. The book was revelatory to me, as it has been for countless others worldwide over the past half-century. For me-the child of Mexican immigrants to California, while experiencing a profound culture shock upon entering an elite private college in Ohio-Freire's modest volume spoke absolute truth to power. I fully embraced Freire's proposal for a fearless pedagogy of freedom grounded in critical educational praxis and radical love, as essential in the ongoing project towards a more humane and just society. A decade later, I found myself walking the favelas and working-class neighborhoods that encircle the megalopolis of São Paulo, observing adult literacy circles, urban classrooms, and teacher circulos de foramação, interviewing educators and reform leaders of Freire's administration of the Municipal Secretariat of Education. ${ }^{13}$ In a letter to teachers, Secretary Freire declared:

\begin{abstract}
We should not call the people to the school to receive instructions, postulations, recipes, threats, reprimands and punishment, but to collectively participate in the construction of a knowledge that goes beyond purely empirical knowledge and that takes into account their necessities and turns it into an instrument of struggle, allowing for their transformation into protagonists of their own history. Popular participation in the creation of culture and education
\end{abstract}

breaks with the tradition that only the elite is competent and knows what the needs and interests of the society are. The school should be a center for the irradiation of popular culture, at the service of the community, not to consume it but to create it. ${ }^{14}$

The audacity of Freire's words of educational transformation within a position of governing power ring boldly relevant today as they are rooted in radical love, "a committed willingness to struggle persistently with purpose in our life and to intimately connect that purpose with what he called our 'true vocation'-to be human." 15 Strange that this centennial celebration of Paulo's birth falls at this moment of global crisis when humanity is at a crossroads. Ever the optimist, Freire would call us to seize the possibilities revealed within the gaping cracks of exiting systemic structures of oppression; and not fall into the trap of re-constructing the old regime. He would urge us to revitalize

13 This research was carried out as part of my doctoral dissertation under my advisor, Carlos Alberto Torres, and published in the book Education and Democracy: Paulo Freire, social movements, and educational reform in São Paulo, [O'Cadiz, M. P., Wong, P. L., \& Torres, C. A, Boulder, CO: Westview, 1998].

14 SME-SP, Cadernos de Formação№ 1, 3ํSérie-AçãoPedagogica da Escola pela via da interdisciplinaridade (February 1990), cited in O'Cadiz, Wong and Torres, 1998.

15 Darder, Antonia. Teaching as an act of love: Reflections on Paulo Freire and his contributions to our lives and our work. California Association for Bilingual Education, 1998. 
our commitment to reflective critical pedagogic action and the democratic transformation of our society's educational institutions. Freire's powerful legacy persists in his many writings and the countless lives he, directly and indirectly, touched and the myriad of educational paths and projects he has inspired. Freire's thought continues to evolve in its reinvention by others, as he would have it, from universities' halls to rural schoolrooms across the globe. 


\section{Celebrando Paulo Freire}

\section{Manuela Guilherme}

Universidade de Coimbra, Centro de Estudos Sociais

A mensagem de Paulo Freire [PF] continua viva um século depois. Um espírito iluminado, visionário e humanista, nascido no nordeste do Brasil, em Recife, estado de Pernambuco, logo no início da $3^{a}$ década do século $X X$, também essa foi fatal, trazendo doença, pobreza e opressão para o mundo e para o Brasil. Estes são três elementos fundamentais para o desencanto e o desânimo. No entanto, PF ofereceu-nos uma 'pedagogia da liberdade' [1991, 1a ed. 1967], que ele concebe como uma oportunidade para a decisão, fundamentada na consciência crítica e no diálogo horizontal, que não se resigna à ajuda assistencial que mascara e preserva a injustiça. Uma 'pedagogia da autonomia' [2007, 1a ed. 1996], através da qual PF nega que 'formar' seja 'treinar', levar o estudante a adaptar-se a uma realidade irreversível: - 'Devo enfatizar também que este é um livro esperançoso, um livro optimista, mas não ingenuamente construído de otimismo falso e de esperança vã' [p. 19]. Assim, PF afirma que 'não há docência sem discência', na medida em que exige o entrelaçar da teoria e da prática, o diálogo epistemológico entre docente e discente. Uma 'pedagogia da esperança' [1993, 1a ed. 1992], a necessidade ontológica que nos mobiliza para transformar e concretizar. Segundo PF: 'Não podemos existir sem nos interrogar sobre o amanhã, sobre o que virá, a favor de que, contra que, a favor de quem, contra quem virá; sem nos interrogar em torno de como fazer concreto o "inédito viável" demandando de nós a luta por ele.' (p. 98). Este conceito de 'inédito-viável' encerra uma promessa de imaginação criativa e energia criadora. Qualquer destas promessas é atingivel paulatinamente, na persistência e na resistência, através da consciência, diálogo e acção críticas. PF legou-nos afinal uma filosofia pedagógica, que vai para além da sua tradução em um método singular, orientada para a educação, a vida cidadã e a acção política. Esta filosofia pedagógica baseava-se numa postura constante de interrogação, uma pedagogia crítica de 'problem-posing' (colocação de problemas] em substituição do que John Dewey preconizava como uma pedagogia de 'problem-solving' (Betz 1992: 119-120, Guilherme 2017]

PF viveu com a instabilidade política e social do Brasil, quer em presença quer na ausência, viveu o exílio no Chile, nos Estados Unidos da América do Norte, na Europa e na África. Esta foi uma experiência muito sofrida, mas deu-lhe uma visão de mundo que Ihe permitiu dar fundações mais sólidas à sua perspectiva anti-colonial e anti-ditatorial da educação, da sociedade e do mundo. Quanto mais se distanciava do Brasil, mais ficava ligado a este. Foi a partir desta vivência internacional e dos contactos que foi estabelecendo que o próprio PF foi lançando as sementes para a existência de uma comunidade freiriana internacional que ainda hoje persiste e que se vai organizando em torno dos Institutos Paulo Freire [Fraga 2016] que continuam a ser fundados em todo o mundo e testemunham a vitalidade do legado de PF. Associações, Forum Paulo Freire, conferências e publicações sobre a obra de PF continuam a ser entusiasticamente organizadas internacionalmente. Como afirma Fraga: - 'o magnetismo de Freire sustenta uma certa conectividade da Comunidade Freiriana que, para além das contradições e diferenças internas, em espaços variados, se faz presente e atuante nas jornadas libertárias e libertadoras da Educação' [2016: 247]. 
Freire foi, de facto, um 'homem no mundo', mas apenas por circunstância, foi um exilado, não perdendo nunca a 'esperança', tão marcante da sua pedagogia e do carácter brasileiro, mas olhando sempre o mundo com o olhar do Brasil, porque ele não decidiu partir, ele partiu, ficando. É esta qualidade que qualifica Freire como um 'pensador do Sul' e a sua obra como uma 'Epistemologia do Sul' [Santos 2016]. Torres [2014] não tem dúvidas em afirmar que PF foi um pensador pós-colonial que coincidia com outros pensadores do seu tempo e também os inspirou como, por exemplo, a Enrique Dussel e à sua filosofia da libertação (p. 112]. A sua voz tornou-se universal, mas os seus discursos não eram universais, pois aqueles estavam comprometidos com um legado histórico e cultural que os enriqueceu. Freire foi um visionário do Sul, sobre o qual reflectiu com base também nas suas aprendizagens de exilado acadêmico. Fora do Brasil, PF foi sempre um exilado do Sul global, como nos confidencia Ana Maria Araújo Freire no seu Prefácio: - "A África é o Continente que fazia Paulo nutrir a ilusão de que "voltava para casa" - quando, então, partia da fria e inodora Suíça para contribuir na constituição, através da educação, das novas nações africanas - tal a semelhança que sentia entre aquele território e aquela gente e o "seu" país e a sua gente"; e prossegue: - "Em qualquer um dos pedaços de terra africana que pisava, reconfortava-se do exilio forçado escutando as pessoas e conversando" [2003, pp. 17-18]. Como esclarecem Romão e Gadotti [2012], PF foi um pensador, pedagogo e activista profundamente empenhado na 'descolonização das mentes'.

\section{Referências:}

Betz, J. [1992] John Dewey and Paulo Freire. Transactions of the Charles S. Peirce Society, 28: 1, 107-126

Freire, P. [1ª ed. 1967] [1991] Educação como Prática da Liberdade. S. Paulo: Editora Paz e Terra

Freire, P. [1 a ed. 1966] [2007] Pedagogia da Autonomia: Saberes necessários à Prática Educativa

Freire, P. [1 $1^{a}$ ed. 1992] [1993] Pedagogia da Esperança: Um Reencontro com a Pedagogia do Oprimido. S. Paulo: Editora Paz e Terra

Freire, P. [2003] A África Ensinando a Gente: Angola, Guiné-Bissau, São Tomé e Princípe. São Paulo: Paz e Terra

Guilherme, Maria Manuela [2017] Visões de futuro em Freire e Dewey: Perspectivas interculturais das matrizes [pós]coloniais das Américas, ECCOS, 44, 205-223

Mafra, J. F. [2016] Paulo Freire, um Menino Conectivo: Conhecimento, Valores e Práxis do Educador. Brasilia: Liber Livro Editora

Romão, J. E. e Gadotti, M. [2012] Paulo Freire e Amílcar Cabral: A Descolonização das mentes. S. Paulo: Ed, L. Editora e Livraria Instituto Paulo Freire

Santos. B. S. [2016] Epistemologies of the South: Justice against Epistemicide. New York: Routledge 


\title{
O sonho possível! 25 anos da Conferência Paulo Freire em Valência Centenário do Nascimento de Paulo Freire
}

\author{
Edineide Jezine \\ Universidade Federal da Paraíba \\ Programa de Pós-Graduação em Educação
}

\section{Carta à Paulo Freire. O sonho possível!}

Parabenizo a iniciativa inovadora da Revista Creativity and Educational Innovation Review [CEIR] em relembrar a presença do educador Paulo Freire em Valência, celebrar a Lei Valenciana sobre a Educação de Adultos e lançar um número comemorativo ao 100ํaniversário do nascimento de Paulo Freire, um cidadão do mundo, um andarilho nordestino da cidade de Recife, que conheceu a pobreza e sonhou com a liberdade, pelas mãos da Educação.

Seu sonho de libertação e transformação da realidade, deixou de ser um simples sonho de menino que brincava de escrever com os gravetos no quintal de sua casa, por que passou a ser o sonho de muitos, milhares de educadores que, ao conhecer suas palavras, se contagiavam pela esperança de transformar a si e, em transformando-se, transformavam os outros e o mundo. A esperança do verbo esperançar que, para Paulo Freire, possui o significado de ir atrás, construir, levantar adiante, juntar-se com os outros para fazer de outro modo, pois a esperança é a experiência histórica do agir do sujeito, como expressa Paulo Freire em Pedagogia da Autonomia [FREIRE, 1996].

É no trilhar do sonho e da esperança que, ao escrever esta carta à Paulo Freire, serei conduzida a refletir sobre o processo de formação que me fez educadora, de como os ensinamentos deste pensador foram definidores das escolhas, ações da minha trajetória e condução da formação do pensar e fazer educativo. E, na busca de me compreender como educadora no mundo, buscar na dialeticidade o sentir do outro, o pensar crítico e o fazer consciente, de modo a, também, difundir o sonho e a esperança que move o educador.

As ideias norteadoras do pensamento de Paulo Freire se fizeram presentes na minha existência, quando, ainda jovem, nos idos dos anos 1980, como estudante do curso de Pedagogia na Universidade Federal do Amazonas [UFAM/Brasil). Conheci Paulo Freire em suas palavras e ensinamentos a partir de docentes progressistas que buscavam nos transmitir o que é ser educador, em um contexto de contradições e desigualdades sociais. Confesso, que não entendia muito bem suas analogias e frases retrucantes de um conjunto de retóricas. Mas, foi a obra Pedagogia do Oprimido que me tocou e firmou a ideia da docência. Na esperança da liberdade e no sonho da transformação social, trilhei os caminhos de professora da Escola Básica à Universidade.

Nos primeiros anos, da experiência como professora da modalidade de Educação de Jovens e Adultos, exercitar a "educação como prática de liberdade", os ensinamentos da palavra geradora, advinda do universo vocabular dos sujeitos, para alfabetizar, exigia um saber diferenciado que, ao mesmo tempo, fosse recheado de audácia e amorosidade aos jovens excluídos do sistema 
escolar. Como eles aprendi que o tempo deixa marcas e saberes populares para a vida, "que não há saberes mais ou menos: há saberes diferentes" [FREIRE, 1996].

A dialeticidade de Paulo Freire, o processo de conscientização e mudança, bem como o princípio do diálogo como uma ação metodológica do fazer pedagógico foram os elementos constituintes para a caminhada de formação. Entendendo que a formação não se esgotava na conclusão do curso, mas na continuidade da prática, do pensar e do fazer. De modo que as palavras emaranhadas, quando do curso de Pedagogia, tornavam-se vivas no fazer pedagógico. E, assim, eu fui me constituindo como educadora, com valores e princípios de defesa de uma educação popular, que se faz com o povo, com as ações que os constitui sujeitos de sua própria história.

Já na docência universitária, como formadora de educadores, passei a navegar nos rios do Amazonas, para a realização de cursos de formação de educadores populares. A participação, junto ao Núcleo de Estudos e Pesquisas em Educação Popular (NEPE/UFAM], possibilitou conhecer a população de municípios como de Tefé, Coari, Itacoatiara, Manicoré, Carauari, dentre outros, e a sabedoria do povo Ribeirinho, Agricultor e Seringueiro, de gente que tem na terra e no rio o sustento e a vida. No trabalho de professora formadora, percebi, na materialidade da ação de alfabetização, como a "leitura do mundo precede a leitura da palavra" [FREIRE, 1985]. Que o meu saber de docente formadora da Universidade não tinha o significado e o significante, se não fosse um saber comprometido com o outro, com sua realidade e a capacidade de pensar e agir de cada sujeito. Que o saber docente torna-se autoritário ao colocar-se como formador e que a educação para a liberdade poderia, também, ser a educação para a opressão. E, nesse agir, compreender que a relação opressor e oprimido, exposta por Freire na Pedagogia do Oprimido, não se constitui apenas uma relação de oposição, em que um poderá tomar o lugar do outro, mas o cerne da divisão de classe e a luta constituinte da transformação social. Nesses termos, na obra Pedagogia da Esperança [FREIRE, 1992), ao revisitar as críticas à obra Pedagogia do Oprimido, afirma sua posição sobre a relação opressor/oprimido, colocando-se como "um insatisfeito com o mundo de injustiças que está aí, ao qual o discurso 'pragmático' sugere que eu simplesmente me adapte [...]", e desta feita reafirma "A luta de classe não é o motor da história mas certamente é um deles" [FREIRE, 1992: 91].

É essa congruência entre o pensar e o fazer, que Paulo Freire demonstra em suas obras, ideias e ações, que conduz jovens educadores universitários na região Amazônica a efetivar nas práticas de alfabetização de jovens e adultos, nos cursos de formação de educadores a educação libertadora. Esta constitui-se o eixo condutor em que a realidade concreta dos sujeitos, inseridos na comunidade, é elemento motivador do diálogo, da discussão da palavra. Em um primeiro momento, as pessoas em sua maioria não levantavam a cabeça, nem a voz para expressar sua opinião, a vergonha e a timidez tomavam conta de jovens, senhores e senhoras analfabetas das letras. Mas, nos surpreendia o rompimento da cultura do silêncio e a aquisição dos processos emancipatórios à medida que o diálogo se propagava e a decodificação das palavras acontecia, os sujeitos se reconheciam como tal em seus saberes, manifestações culturais e ideias, se reconheciam em sua força de organização para a transformação. E foi, desta forma, que compreendi que "Ninguém educa ninguém, ninguém se educa a si mesmo, os homens se educam entre si, mediatizados pelo mundo" [FREIRE, 1987).

A assertiva que a educação, em seus processos educativos formais e não formais, constitui-se um ato político e instrumento de libertação, conduziu-me a escrita da dissertação "Universidade e Saber popular. O Sonho possivel" [UFPB, 2002], em que se analisam as experiências de extensão 
universitária em educação popular do Brejo paraibano ${ }^{16}$, uma outra realidade social, mas não menos opressora. As experiências de educação popular se processam sob os fundamentos da concepção Freireana e a extensão constitui-se o elo entre universidade e sociedade. Nessa escrita, a reflexão emerge sobre o papel social da Universidade, a partir da extensão universitária, temática que me acompanha como pesquisadora e tem, no ensaio "Extensão ou Comunicação?" [FREIRE, 1983], o fundamento e a concepção teórica da extensão como um ato de comunicar, em que o diálogo se constitui o eixo da prática extensionista.

A Extensão universitária, presente na trajetória de educador de Paulo Freire, na Universidade do Recife, deu-lhe a oportunidade de vivenciar as desigualdades sociais, retratadas pelos altos índices de analfabetismo. É a sua indignação ao estado de consciência do povo e à condição de analfabeto, que o faz pensar sobre a importância do ato de ler, e a forma de ensinar constituindo a crítica à escola bancária e ao analfabetismo, como uma das expressões concretas de uma realidade social injusta. Paulo Freire, ao denunciar as injustiças sociais como situações de opressão, chama-nos a refletir sobre a nossa condição de existência na sociedade. Desta feita, na Pedagogia da Esperança [1992:91], Freire reafirma a importância das utopias, pois "não há utopia verdadeira fora da tensão entre denúncia de um presente tornando-se cada vez mais intolerável e o anúncio de um futuro a ser criado, construído, política, estética e eticamente, por nós mulheres e homens".

Nesse sentido, o pensamento de Paulo Freire vive, e nos chama a fazer a história, a sermos protagonista da nossa própria história, a entender a história como possibilidade e não como determinismo que elimina o sonho. 0 sonho é um pensamento estratégico da realização do sujeito insatisfeito com a realidade. "O sonho se faz uma necessidade, uma precisão" [FREIRE, 1992:100) pois, a partir dele podemos romper, com a naturalização das injustiças e condição de pobreza que separa nações, classes, grupos e pessoas, é condição. O Sonho é a condição da esperança existir, desta feita o pensamento de Paulo Freire, continua vivo, quando ele nos alerta à denúncia e ao anúncio do possivel sonhado.

Paulo Freire sempre viverá na educação brasileira e mundial, seja como patrono da educação, seja como um simples educador, pensador, autor de livros ou outras denominações, por que o mundo o conheceu e conheceu sua capacidade de sonhar e esperançar, habilidades raras em tempo de isolamento social e neoconservadorismo, mas necessárias para manter a humanidade acautelada à condição humana.

Minha homenagem e agradecimento à Paulo Freire se estende ao mestre José Beltrán Llavador, da Universidade de Valência, que sonha e espalha esperanças com sua leveza e conhecimento, um educador que se emociona ao falar das possibilidades de uma universidade para todos e todas e seus ensinamentos e aprendizagens nas classe de adultos, um educador que exercita o pensar e o fazer freireano, agradeço o carinhoso convite e a oportunidade de revigorar o meu sonho de um mundo mais justo e de uma universidade popular, pois, como uma das milhares educadoras que sonha, Paulo Freire vive presente e renova o educador de cada um de nós. "A educação é um ato de amor, por isso, um ato de coragem. Não pode temer o debate. A análise da realidade. Não pode fugir à discussão criadora, sob pena de ser uma farsa" [FREIRE, 1999].

16 É uma das 23 microrregiões do estado brasileiro da Paraíba, com população estimada pelo IBGE, em 2017, em 115.000 habitantes. Refere-se às áreas altas do Nordeste, que são mais úmidas, onde prevalece o verde. 


\section{Referências}

Freire, P. A importância do ato de ler. Col. Polêmicas do Nosso tempo, Editora Cortez, São Paulo, 1985.

Freire, Paulo. Pedagogia do oprimido. Rio de Janeiro: Paz e Terra, 1987.

Freire, Paulo. Pedagogia da Autonomia: saberes necessários à prática educativa. Publicação original 1996.

Freire, Paulo. Pedagogia da Esperança. Um reencontro com a Pedagogia do oprimido. Rio de Janeiro. Paz e Terra, 1992.

Freire, Paulo. Educação como prática da liberdade. 23_a ed. Rio de Janeiro: Paz e Terra, 1999. 


\title{
Por un mundo mejor
}

\author{
Alejandra Montané \\ Universidad de Barcelona
}

Hoy quiero enviar mi agradecimiento a los organizadores de esta propuesta, compañeros y compañeras de Valencia que nos invitan a compartir esta emotiva celebración del centenario de del nacimiento de Paulo Freire, este próximo 2021, así como el veinticinco aniversario de la conferencia que impartió en la Universidad Internacional Menéndez Pelayo. Me alegra poder compartir este saludo y reconocimiento a Paulo Freire sabiendo que mantenemos viva la llama de la esperanza y que continuamos habitando algunos lugares comunes en tiempos de tan elevada incertidumbre.

Se trata de un saludo académico y personal desde la humildad de quien sabe que continúa aprendiendo lenta y dolorosamente a veces. Paulo Freire nos ha acompañado. Acompañó mis tiempos de estudiante apasionada con la utopía de la libertad, cuando abrazaba los textos que me encendían e incendiaban intelectualmente y que han participado en la creación de mi propia identidad profesional y percepción del sentido de la educación. En ocasiones disfrutando y aprendiendo, a veces indignándome o exaltándome. Intentando ser en la práctica y viviendo en esa curiosidad epistemológica que también aprendí de él, y que, como bien manifestaba, es intrínseca a lo humano, ontológica, por lo tanto. Me entregué más tarde, y en múltiples ocasiones, a una lectura más serena de sus textos, haciendo mía la vigencia actual de la pedagogía del oprimido, la necesidad vital de indignarse, la conciencia esencial de la vigilancia epistemológica y, principalmente, esa concepción ontológica del ser humano en construcción. Cuánta riqueza y complejidad en un pensamiento tan contextual que tiende una mano que te invita y te lleva suave e inteligentemente a mirar de frente y con valentía la injusticia social. Y hoy, más que nunca, me rindo a su llamada a la esperanza que tanto precisamos como condición necesaria para la existencia humana, como posibilidad de ser.

Freire está en cada uno de los proyectos que emprendo y forma parte de mí. Siempre acompañada de freirianos y freirianas que a través de muchos proyectos y encuentros hemos intentado mantener el espíritu, reinventar y recontextualizar los saberes y conocimientos construidos colectivamente -desde muy distintos lugares del mundo y muy distintas perspectivas- que aprendimos de sus innumerables publicaciones y conferencias de una vida llena de sabiduría.

En el centenario de su nacimiento, saludo a la esperanza y a la celebración de la vida. Por un mundo mejor. 


\title{
Minha homenagem ao Prof. Paulo Freire, pelo privilégio de ter estado sob seus ensinamentos.
}

\author{
Profa ${ }^{-}$. Dra. Betania Leite Ramalho - UFRN
}

Tive a sorte de conviver, em algumas ocasiões, com o professor Paulo Freire. Uma delas durante os seminários, como aluna do Mestrado em Educação de Adultos da Universidade Federal da Paraíba. Eram encontros de tirar o fôlego! Um provilégio poder escutá-lo e aprender diretamente com ele, com sua simplicidade, modéstia e maneira mágica de nos brindar com explicações sociológicas, filosófica, pedagógicas e políticas sobre o mundo, a sociedade, a educação escolar, as contradições e desigualdades sociais no mundo. Por razões políticas, minha geração não teve acesso às obras "freirianas" na formação universitária. Por incrivel que parece, manuseei [com muita reserva] um primeiro livro de Freire, Educação como Prática da Liberdade, exatamente em Santiago do Chile, em 1978, período das ditaduras militares [Brasil, Argentina e Chile], ocasião em que estudei no Centro Interamericano de Estatísticas, CIENES, Santiago.

Um outro momento marcante foi estar presente na solenidade da Título de Prof. Honoris Causa, 1988, concedido a ele pela Universidade de Barcelona. Fotografei todo o evento e cheguei a entregar-lhe as fotos em 1993, em Natal, no Rio Grande do Norte [RN], Brasil. Como retribuição ganhei dele o livro Biobiografia e uma carinhosa dedicatória: "Para Betania, relembrando Barcelona".

A essas lembranças se somam outras mais recentes: a comemoração do Cinquentenário das 40 Horas de Angicos [1963), cidade do RN onde foi testado o método de alfabetização de adultos. Estando à frente da Secretaria de Educação do Estado do Rio Grande do Norte (entre 2011 e 2014], coordenei, junto a um grupo de professores freirianos, nomeado pelo Ministro da Educação Aloísio Mercadante, o evento comemorativo. Foi um momento singular em que conseguimos mobilizar professores amigos do Paulo Freire, representantes das Cátedras UNESCO/EJA, dos Centros e Institutos Paulo Freire, de Universidades do país e do Exterior, a Fundação Roberto Marinho, ex-alunos remanescentes e alfabetizados nas 40 Horas de Angicos, entre outras autoridades e políticos.

Essas lembranças e as manifestações à sua memória, reforçam nossas convicções por meio das ideias, dos princípios assumidos, do compromisso social que nos unem e nos desafiam, permanentemente. Nesse momento em que está sendo celebrado os 25 anos da Conferência Paulo Freire em Valência [1995), me somo aos colegas da Universidade de Valência e de muitas outras instituições que continuam a enaltecer o pensamento de Freire e a reinventá-lo. Sou grata pelo convite em participar desse momento. 